\title{
MaPA and EdiPA: two analytical tools for text-sound-image interrelations in music videos
}

\author{
Fausto Borém \\ Universidade Federal de Minas Gerais \\ faustoborem@gmail.com
}

\begin{abstract}
Two consecutive analytical tools are presented here: MaPA (Map of Audiovisual Performance) and EdiPA (Audiovisual Performance Edition). I introduce these tools as a possible way of organizing and representing the content of music videos as primary sources of analysis. Both tools aim at understanding the interrelationsof the trinomial text-sound-image which is fundamental to the interaction between musical performance and its context. The construction of a MaPA begins with the selection of isolated photograms or a sequence of photograms extracted from a video with the intention to show the relationships between music and staging elements (facial expressions, larger body gestures, props, lighting, camera effects, image manipulation, filming techniques etc.). The EdiPA is built to graphically highlight fundamental sound elements which are transcribed from the video with some kind of music notation (such as the traditional score, lead sheets, graphics, spectrograms etc.) over which photograms from $\mathrm{MaPAs}$ are overlaid with its respective video timings (in minutes and seconds) and a succinct textual information to facilitate the comprehension of the text-sound-image trinomial. The use of both analytical tools is illustrated here with various types of MaPAs and EdiPAs samples, from simple ones to more complex ones. I also propose the recognition of three types of music video recordings (illustrated here with performances of Brazilian singer Elis Regina and singer-composer Caetano Veloso), which consider the interference of the video direction and the levels of freedom and planning of the musicians' performance: (1) non-spontaneous performances, (2) quasi-spontaneous performances (3) spontaneous performances.
\end{abstract}

Keywords: music video analysis; text-sound-image relationship; music analysis tools; performance by Elis Regina; composition and performance by Caetano Veloso. 


\section{1 - On the analysis of music videos}

Two technological innovations - recording/playback of sound sources in the mid-19th century ${ }^{1}$ and simultaneous recording/playback of sounds and moving pictures in the late 19th century ${ }^{2}$ - changed the way we hear-see music realization. The sensorial reinforcement generated by the combination of sound and visual stimuli in automatic reproduction of recorded performances enhanced the perception of artistic expression. In music, listening to musical instruments, voice and other sound sources coupled with the enjoyment of performance images (with or without significant movements) and its surroundings, has expanded its meanings on many levels, noticeable in the signs of the Peircean basic triad: icons, indexes and symbols (Merrell, 2010, p.31, 37). A relevant adaptation of these parameters to music was proposed by Dowling and Hardwood (1996), which combine psychoacoustic, cognitive, and ethnomusicological issues. ${ }^{3}$

The pioneering British initiatives in using historical music recordings as primary sources for musicological research was coordinated and optimized in two national initiatives in the early 21st century, both sponsored by the British research agency Arts and Humanities Research Council. First, the creation of CHARM (Centre for the History and Analysis of Recorded Music) ${ }^{4}$ in 2004; and, then, its replacement by CMPCP (Research Centre for Musical Performance and Creative Practice $)^{5}$ in 2009. These initiatives encouraged the development of

\footnotetext{
${ }^{1}$ The first audio recordings of music were made on April 9th, 17th, and 20th, 1860, by a French man named Édouard-Léon Scott de Martinville (Feaster, 2010, p.60-70, 73, 81), seventeen years before Thomas A. Edson's patent. With his phonoautograph, patented March 25th, 1857, ÉdouardLéon recorded the French folk song Au Clair de la Lune. One of these recordings can be appreciated at https://www.youtube.com/watch? v=s0fhEpxrFvo (Martinville, 1860, published in 2008).

2 The first fruitful attempts to combine music with the recording of moving images date from 1895, with the kinethophone of Thomas A. Edison; and 1902, with the chronophone of Léon Gaumont (Gomery, 1985, p.8-9). The first film with live music, The Dickson Experimental Sound Film, realized by William Dickson with kinethophone between the late 1894 and early 1895, shows himself playing Song of the cabin boy (from the operetta The Chimes of Normandy by Robert Planquette, 1877) and it can be appreciated on Youtube from [0:44] to [1:01] through the link https://www.youtube.com/watch?v=vfqUjBDIkT8 (Dickson, 1894-1895, published in 2013).

${ }^{3}$ For Dowling and Hardwood (1986), a musical index imposes an association between music and a non-musical event/object; a music icon expresses a formal similarity between a signal and music; a musical symbol refers to internal syntactic relations on the musical field itself.

${ }^{4}$ CHARM was established in 2004 as the result of a partnership among four institutions: University of London, Royal Holloway, King's College London and University of Sheffield.

${ }^{5}$ CMPCP, which replaced CHARM, was established in 2009 and resulted from a partnership among seven institutions: University of Cambridge, King's College London, University of Oxford, Royal Holloway, University of London, Guildhall School of Music \& Drama and the Royal College of Music.
} 
analytical tools for recorded music, such as software that deals quantitatively with tempo, dynamics and articulation parameters. ${ }^{6}$

Despite increasing results and socialization of music audio analysis, we see a great lack of research work and analytical tools addressing music video files. In the late 20th century, Cook observed that

"... the widespread inability of commentators to find anything to say about the music of music videos may result from the lack of an adequate theoretical basis for relating what is heard to what is seen [...] Even the best writing on music videos [...] is undermined by the relative crudeness of its categories for the description and analysis of musical structure. Most researchers [...] do not even perceive this as a problem, and the inevitable result is that music videos almost always end up being analyzed as videos, but not as music. As I said, 'Material Girl' [song by Peter Brown and Robert Rans on the album 'Like a Virgin' by pop singer Madonna] is one of the most highly theorized of all music videos, but in all this literature I have yet to find a single sentence specifically about the music" (Cook 1998, p.150).

Today, nearly two decades after the release of the seminal book Analyzing Musical Multimedia, Nicholas Cook (1998), ${ }^{7}$ there still is a great gap in this promising research trend between musicology and music performance, an interface Goodwin (1992 p.49- 71) called "musicology of the image."

Considering the 11 research events with participants from various countries, organized by CHARM/AHRC and disclosed in their homepages (20042008), only 2 out of 159 research communications dealt with music analysis in videos (AUSLANDER, 2015; CLAYTON, 2007) ${ }^{8}$.

\footnotetext{
${ }^{6}$ Among the software created at CHARM to analyze recorded music are Scape Plot Generator, Data Smoother, Correlation Network Diagram Generator, Sonic Visualiser, Session Editor, Tap Snap, Dyn-AMatic, Keyscapes and Expression Algorithm.

${ }^{7}$ Cook (1998) divides his book Analyzing musical multimedia didactically into two parts: the first, with general theoretical principles and literature review, and the second, with case studies.

8 The events and works about recorded music organized by CHARM and listed in its homepage are: the seminar Representing Performance: Musical Recordings in Culture (with 9 communications, Royal Holloway, University of London, 30 October, 2004); CHARM Symposium 1: Comparative perspectives in the study of recordings (13 communications, Royal Holloway, University of London, 14 to 16 April, 2005); CHARM Symposium 2: The art of record production (11 communications London College of Music and Media, 17 and 18 September, 2005); West Focus seminar 1: Teaching resources for recorded music (6 communications, King's College London, October 1, 2005); CHARM Symposium 3: Transfer and the recording as historical document (13 communications, Royal Holloway, University of London 20 to 22 April, 2006); West Focus Seminar 2: Hold that sound! Recording your amateur orchestra or choir (5 communications, Bertorelli Restaurant and Bar, London, 30 May 2006); West Focus Seminar 3: Creative production in classical music (5 communications, King's College London, June 5, 2006); CHARM Symposium 4: Methods for Analyzing recordings (18 communications, Royal Holloway, University of London, 12 April 14, 2007); CHARM / RMA Annual Conference: Musicology and recordings (36 communications, Royal Holloway, University of
} 
Similarly, considering the 100 publications listed by CHARM on its website (http://www.charm.rhul.ac.uk/studies/p6_1_4.html), only one seems to address this issue (Cook, forthcoming, listed 2009). In fact, Nicholas Cook was a pioneer in the analysis of music recorded not only in audio files but also in videos. In his book on this subject, he proposes that we to look into the need to "... extend the boundaries of music theory to encompass - or at least map the frontier with - words and moving images (and bodily gestures too, though I say less about them [in this book]..." He draws attention to the need for "... swim against the tide of film criticism and other narrative-based approaches which reduce the role of music [and, therefore, the analysis of music videos] to that of a mere supplement - when it is mentioned at all" (Cook, 1998 p.vi).

From the point of view of understanding the musical phenomenon, Nicholas Cook (2013, p.251-252) refers to the analysis of recorded music as "the ethnographic turn" in musicology for the 21st century. My contact with the works done or organized by CHARM (Cook and Chan 2007) supported my idea that research in music performance with audiovisual as primary sources would be my main research trail and guidance in graduate school.

The limitations of the primary sources consisting of texts and music scores motivated me to seek out relevant information first in audio recordings and later in music videos. The analysis of audio and video files were essential to me and my students to better understand the compositional and performance styles of several references of Brazilian music, ${ }^{9}$ especially in popular music, with a history of ample recognition by international audiences and critics. In order to reduce the scope of this paper, I sketched an organizational chart (see Figure 1 above) to situate vertically the universe of videos. First, going down into analytical categories to, at the other end, allow a synthesis that makes explicit subliminal or hidden relationships that are not readily observable at first sight and/or hearing. The meanings of the trinomial text (or context)-sound-image can be better explained to the reader through the tools MaPA and EdiPA.

London, 13 September 15, 2007); CHARM Symposium 5: Cultures of recording (19 communications, Royal Holloway, University of London 10 to 12 April, 2008); CHARM Symposium 6: Playing with recordings (15 communications, Royal Holloway, University of London 11 to 13 September, 2008).

9 Published research from the PPP Research Group ("Pearls" and "Hot Potatoes" of Musical Performance) includes audio and/or music video analysis of music by Hermeto Pascoal, Egberto Gismonti, UAKTI Group, Milton Nascimento, Toninho Horta, Elis Regina, Serge Koussevitsky, Francisco Mignone, Radames Gnattali, Pixinguinha, Bonfiglio de Oliveira, Porfirio Costa, KXimbinho, Zé Bodega , Abel Ferreira, Victor Assis Brazil, Raphael Rabello, Salvador Amato and, still in progress, Zé da Velha, Caetano Veloso, Jaques Morelenbaum and Belini Andrade. 


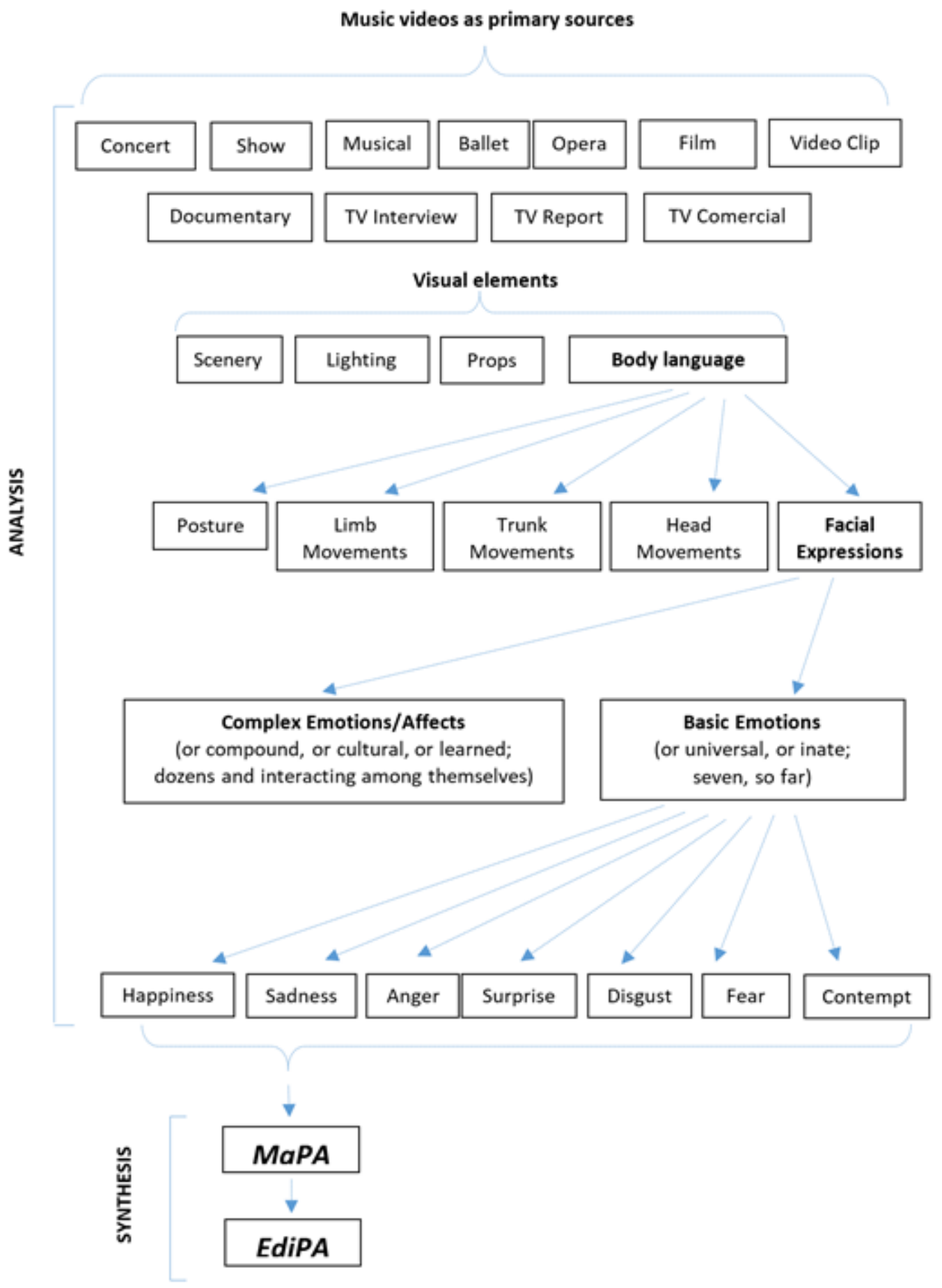

Figure 1 - Chart of imagetic primary sources, analytical designs for music videos and two tools (MaPA and EdiPA) proposed for visual synthesis of analytical data.

It is still premature to speak of a comprehensive theory for the analysis of music videos. In this article, however, I dare to present some procedures that culminate in these two tools aimed at summarizing and presenting the data that result from this type of analysis: the MaPA (Map of Audiovisual Performance) 
and EdiPA (Edition of Audiovisual Performance). My trajectory in the development of these two consecutive analytical tools (because MaPAs are the basis for the construction of EdiPAs) began with an eclectic motivation. My experiences in the field of Civil Engineering and then Architecture, although incomplete, allowed me to approach measurement, organization, aesthetics and graphical representation of the physical spaces occupied by artists during their performance. On the other hand, a long history with sports and a multidisciplinary collaboration with colleagues from the Motor Behavior field (a branch of Physical Education) allowed me to see and describe details of the body in motion. Finally, my experience in the preparation of musical examples as the Editor-in-Chief of a scholarly music journal in Brazil and graphic animations that I include in my lectures gave me the visual support needed to get a more objective and concise representation of events and their kinesthetic relations (aural + visual) in music videos.

As in any good culinary recipe, choosing the main ingredient - the primary source consisting of a music video - is a determining factor in the quality of the final products ( $M a P A$ and EdiPA). As a good and eclectic cook of musical analysis, Nicholas Cook (1998, p.150) suggests that “... [it] might be possible to work from fairly basic music-theoretical concepts towards an understanding of the relationship of music with words and pictures...". In fact, both MaPA and EdiPA can be constructed to pinpoint simple interactions that require little musical knowledge. However, when selecting a music video, the analyst should consider, in addition to the quality of sound and image and the expressive potential (meanings, cohesion, originality and evidence of relevant text-soundimage relationships), their skills to address the musical matter (tonal, modal, atonal, serial, ethnic languages, concrete music, soundtrack etc.; styles and performance practices of popular and learned genres) and their culture in relation to music context (compositional motivation, programmatic and social aspects, etc.).

The main repositories of music videos are websites on the internet and, therefore, I recommend that you download the video you are going to analyze in order to not lose the virtual primary source. The internet also provides videos (professional and amateur) that can reveal raw data, which, once transcribed, can result in unpublished interviews and relevant musical data missing in printed literature. An example can be taken from the movie "Dzi Croquettes" (Issa and Alvarez, 2009), in which Luis Carlos Miele (2009, from [03:00] to [3:25], Figure $2 a)$, in order to illustrate the transgressing and improvisatory spirit of the dancer, actor, musician and director Lennie Dale, narrates his changes at the end of the classic bossa nova hit "Você e eu" ["You and Me"] by Carlos Lyra and Vinicius de Morais. In the video, Miele says Dale used to replace "...Eu sou mais você e eu" ["... I am more of you and me"] in the original lyrics by the little longer "...Eu sou mais 
você e meu amor" ["... I am more you and my love"]." More than this, Miele tells Dale also modified melody and harmony, suggesting "... a completely strange tonality ..." and challenged bossa nova experts, saying “... Mas, por que ninguém fez assim, não pode? Tá errado? Vamos fazer, fica lindo!". [“... But, because no one has done so, it does not mean we can't! Is it wrong? Let's do it, it is beautiful!"]. Also in the video, Miele sings with an accent, imitating the version of the American eclectic, the transcript of which is shown in Figure $2 b$ (Borém and Taglianetti, 2014th, p.43).
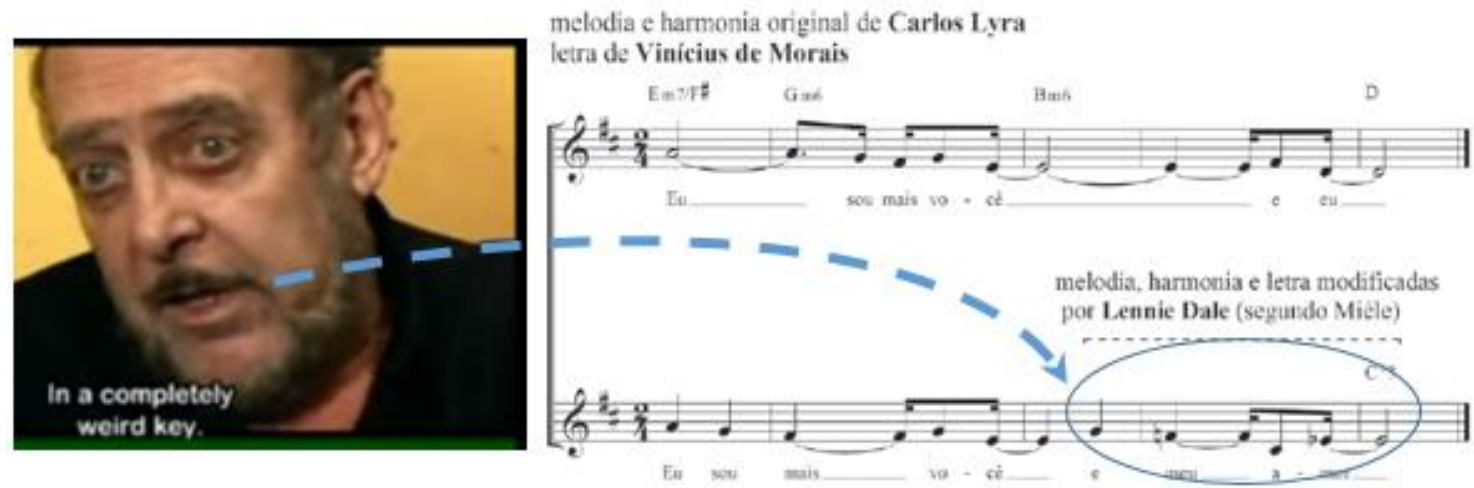

Figure $\mathbf{2} \mathbf{a} / \mathbf{2} \mathbf{b}$ - Transcript of speech and sung passage (lyrics, melody and harmony) in Miele's interview (2009, from [03:00] to [3:25]) about the improvisatory style of Lennie Dale.

In the present article, videos of two artists with long and lasting contributions to Brazilian music are used as the source of analysis: Elis Regina, whose iconic performances on stage made her a symbol of the complete performer; and Caetano Veloso, whose production as a composer, arranger, lyricist, singer (in several languages and styles), guitarist, cultural activist and performer have transformed him into a symbol of an eclectic musician. In relation to planning music realization and expressing spontaneity in performance, I give examples of MaPAs with three types of filming: (1) non-spontaneous performance, in which there is a carefully planned script, with the performers actions being controlled, without any effort to convey the feeling of spontaneous natural actions, highlighting the work of film and image editing; (2) quasispontaneous performance, in which musical realization seems natural and with little image editing work, but with signs of stage direction and event coordination; and (3) spontaneous performance, in which the stage/video director and musicians do not control music realization. Thus, even if momentarily, they are not tied to a script (or they lose this control) what yields unexpected actions, such as errors, unplanned emotions and events that, in principle, are not reproducible. 
Within the multidisciplinary literature needed to address the trinomial relationship text-sound-image, I highlight the fields of Anthropology, Psychology, Psychiatry, Social Studies, Neurosciences, Physiology, Motor Behavior, Kinesiology, Linguistics, Theater and Dance. In order to analyze the gestures of performers in music videos, I resort to five concepts proposed by Haga (2008) to analyze dance movements which were adapted to music (Borém, 2014), namely: (1) Chunking, which divides the whole performance into smaller autonomous units, gesturally well marked; (2) Activation Contour, which are changes in activity or energy levels that characterize a Chunk (a sound or a movement segment of the Chunking process) or changes in one of the motion parameters in gestures: Kinematics or Dynamics (both derived from physics); (3) Kinematics, which relates to the path and change in gesture speed; (4) Dynamics, with respect to the forces for initiating or constraining a movement (intensities here do not have the same meaning that is traditionally used in music); (5) SyncPoints, which are relevant synchronization points between music and gesture. I also resort to dancer-choreographer-playwright Rudolf Laban (1879-1958) to observe, situate and describe the human body on stage inside the limits of its Kinesfera $^{10}$ (Rengel, 2001) in relation to the dimensions and gradations he proposes: Effort, Space, Time, Weight and Flow (Laban, 1978). Although Laban has been a pioneer in the systematization of concepts about movements of performers on stage, consolidated studies in Sports Sciences have demonstrated a more objective view in the fields of (1) Motor Behavior, which seeks to understand the processes and mechanisms related to production and acquisition of body motion (for applications in music, see Lopes, 2015; Borém, Lopes and Lage, 2014; Lage, Borém, Benda and Moraes, 2002), and (2) Kineosiology, which analytical approaches (Hall, 2005; Hamill and Knutzen, 2008) technically describe human movements as to its accuracy, distinctness, stability and cognition (Magill, 2000; Schmidt and Wrisberg, 2001).

From the point of view of the face, which is the part of the human body where most of the emotions are expressed, I turn to recent findings in the field of psychology and anthropology, primarily resulting from the interaction between two approaches: first, the evolutionist (or innate, or universal), which began in the late 19th century with naturalists and, then, the anthropological (or learned, or cultural), which emerged in the mid-20th century. Today, there is a relative agreement between these two trends as far as a reduced number of emotions

10 Kinesfera is the imaginary sphere around the body (Rengel 2001, p.37-38) which limits are determined by the maximum length of their extremities (limbs) or, as far as I could grasp in the literature, projecting parts (such as the head) or parts that may be moved to become prominent (pelvis, buttocks, etc.). For didactic and practical purposes, Laban reduced the Kinesfera to the geometric volume of the icosahedron (Rengel, 2001, p.84), with its 12 vertices and 20 faces, within which Laban recognizes 27 possibilities of movement directions (Rengel, 2001, p.17). 
which are considered innate (Ekman and Keltner, 1997; Keltner and Ekman, 2008; Ekman, 1999; Ekman, 1972): joy sadness, surprise, anger, fear, disgust and, more recently, contempt (Ekman and Friesen, 1986); these are observable even among babies (Burt, 1994; Izard, 1982; Izard and Dougherty, 1980; Izard and Dougherty, 1982). The recognition of these 7 basic emotions in facial expressions is indicated by the actions of 43 facial muscles (Foreman, 2003). The basic expressions, subject to visual recognition (Ekman and Friesen, 2003) may become complex because they can connect to each other (for example, surprise incorporating anger or fear) or overlap themselves (for example, simultaneous joy and sadness). Moreover, especially influenced by the culturalist view, there are studies suggesting that facial expressions can be learned or mimicked (Birdwhistell, 1952, 1970), what includes subtle gradations of the basic emotions. In his evolutionary approach, reflecting basic survival instincts, Plutchik (2001, p.348-349) pairs eight basic emotions in opposite poles (i.e, joy/sorrow, trust/disgust, fear/anger, surprise/anticipation), whose circumplex model also includes increasing intensity gradations (e.g., apprehension/fear/terror, serenity/ joy/ecstasy etc.). Although he notes that language itself makes description of emotions ambiguous (e.g., differentiating shame and guilt, or jealousy and envy; Plutchik, 2001, p.344), tables with descriptive terms arranged in families of feelings, such as the linguist Kaitlin Robbs's proposal (PARR, 2016), whose circle of adjectives/nouns in three levels of detail (with 6, 36 and 72 descriptive words, respectively) may help in the recognition and description of feelings in music.

A recent step in the recognition of facial expressions was proposed by $\mathrm{Du}$, Tao and Martinez (2014), who consider a net of combination of hues among the basic emotions. By means of measuring muscle movements in the face, Du and Martinez (2011) reached a set of 22 compound (or complex) emotions. Another contribution within the universe of basic and complex emotions, Russell (1980, p.1174) offered his Circumplex Model of Affects with the subtleties in the most common moods forming a circular continuum whose borders are not rigid. He proposed 28 adjectives distributed in the four quadrants of the Cartisan Plane to describe affective sensations according to more negative or positive valences in the x-axis (varying from "depressed" to "happy") and according to less or greater energy or stimulation levels in the y-axis (varying from "sleepy" to "excited"). Figure 3 shows an adaptation and application of this model in the planning of a theatrical plot for the performance of Lino José Nunes (1789-1847)'s three Imperial Brazilian songs (modinhas), which dramaturgy (tension-sadnesshappiness) was motivated by the analysis of the trinomial lyrics-music-scene (Borém e Taglianetti, 2016). 


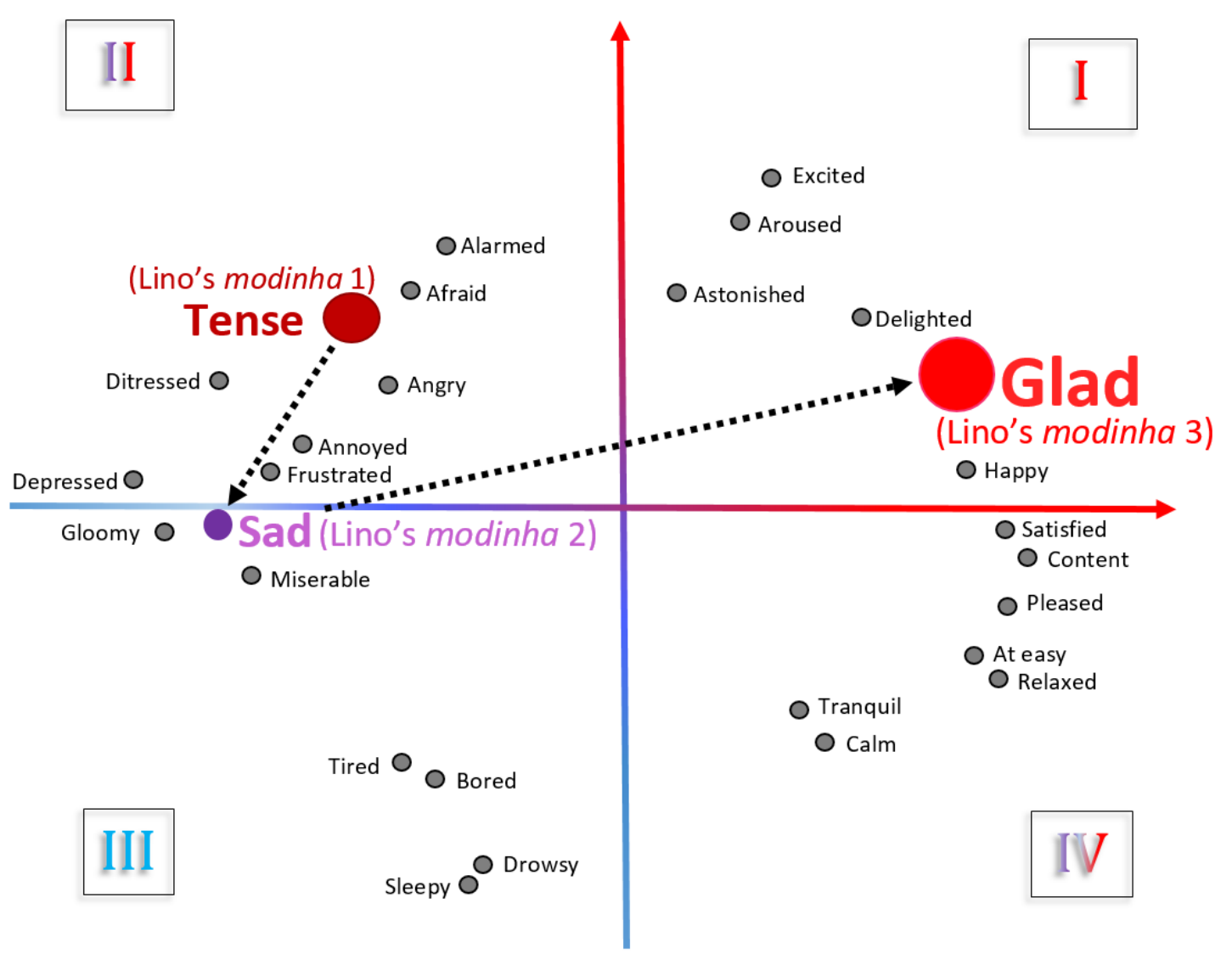

Figure 3 - Russels's Circumplex Model of Affets (1980) adapted to music (Borém and Taglianetti, 2016; Borém and Campos, 2016) in the construction of a plot (tensionsadness-happyness) for a theatrical performance of Lino José Nunes's three Brazilian Imperial songs.

Among other studies that may help identify and characterize elements present in music performance practices, I mention the study by Sauter (2006, p.197-210), which also corroborates the universality of some human expressions and focuses on the communication of atmospheres and emotions in verbal and non-verbal vocalizations related to body language. The paradigmatic analysis by Tagg (2011) brings the possibility to analyze and recognize emotional traits with an illiterate vocabulary in music realized/appreciated by "non-musos", a term he coined to contemplate the enormous category of intuitive musicians without classical training. In his literature review, Juslin (2001) sought to identify the occurrence of emotional character descriptors in musical realization, including "multiple layers" that consider emotions beyond the basic emotions, i.e., more complex (or compound), observed in expressive resources of singers and instrumentalists. In another literature review, quite extensive (145 studies), Juslin and Laukka (2003) confirmed the close relationship between vocal expression in humans and emotions in music, which reinforces the idea of great and intrinsic 
expressive potential in singing. Studying the interaction between musicians and their audiences, Kawase (2014) noted the importance of 10 visual and auditory cues (facial expression, gaze, body gestures, posture, touch, interpersonal distance, verbal information, attire, breath and musical sounds) as far as the function of producing or appreciating music (artists versus audience) and style (classical versus popular). Dahl (2006) verified the communication of three emotions (anger, joy and sadness) in gesture patterns (amplitude, tempo and movement speed) in instrumentalists (marimba, saxophone and bassoon players). An alternative to the artificiality of the experimental studies in the controlled environment of laboratories and the hackneyed approach of autoethnographic reports, or research with questionnaires about expressiveness in music, has been presented by Torres-Eliard, Labbé and Grandjean (2012). They propose a neurosciences approach that uses a continuous evaluation of emotions throughout a musical performance in a real concert situation. 14 participants (dilettantes of classical music) attended the live presentation of the Quartetto di Cremona playing Bartok and Schumann's music and, according to three levels of intensity (low, medium and high), judged effectively nine emotional dimensions of the GEMS (Geneva Emotion Music Scale) scale proposed by their research group: "wonder", "transcendence", "tenderness", "nostalgia", "peacefulness", "power", "joyful activation", "tension" and "sadness". This approach opens a perspective for a better understanding of atmosphere changes in music, observed between activation contours, a concept proposed in psychiatry by Stern (2000 and 2004).

\section{2 - The construction of a MaPA (Map of Audiovisual Performance)}

A MaPA consists of a set of selected frames extracted from a music video, to which are added graphics and succinct textual indications from the lyrics (or from texts about the music), movements and stage elements of the performance. First, I will present single-frame MaPAs in Figures 3, 4 and 5. For this video, the song "Atrás da porta" ["Behind the door"] (Regina, Buarque, Hime and Oliveira, 1973), recorded in studio for TV received an arrangement according to the form Intro - A - B1 - B2 - Coda. Elis Regina, who I consider an archetypical symbol of the text-sound-image integration in musical performance, uses pauses in the voice lines to express, through facial expressions, feelings that meaningfully enrich the content of the Chico Buarque's lyrics. All three single-frame MaPAs exhibit moments in which the singer's facial expressions may be associated with affects that are part of the complex universe of the song's character: the end of a love affair from the point of view of a submissive woman who, emotionally, departs from anger, going through sorrow to arrive at arrogance. In Figure 4, at [1:23] of the video (the beginning of Section B1), with an upright back, but with 
the eyes looking down, she takes advantage of a pause in the singing, right after "...e me arrastei, e te arranhei..." ["... and I dragged myself, and I clawed you..."], the singer projects, contracts and folds the upper lip against the lower lip, and clench the microphone with both hands, suggesting the basic emotion of anger (Ekman and Friesen, 2003, Figure 37), reflecting a complex cocktail of emotions: an index of aggressiveness ("... I clawed you...") as an immediate reaction to an index of humiliation ("...I dragged myself..."), what will be followed by indexes of regret (Figure 5) and arrogance (Figure 6).

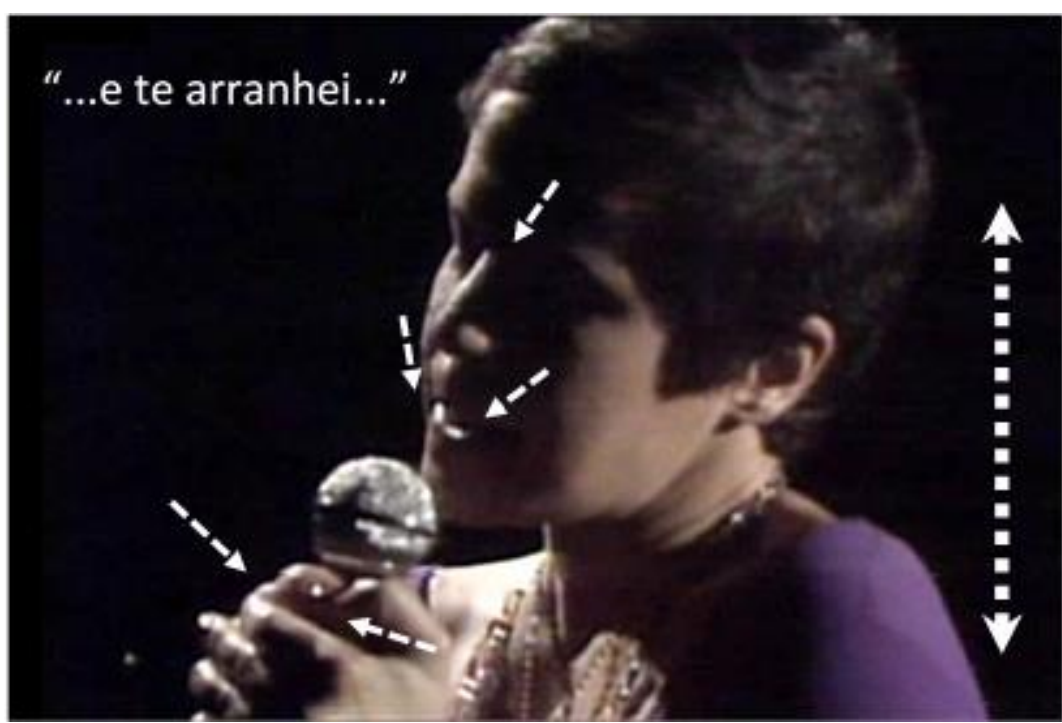

Figure 4 - A single-frame MaPA of Elis Regina expressing anger (Regina, Buarque, Hime and Oliveira, 1973) performing "Atrás da porta" ("... and I clawed you ..." at [1:23]) by Chico Buarque: looking down, upper lip folding over a tense lower lip, clenched hands.

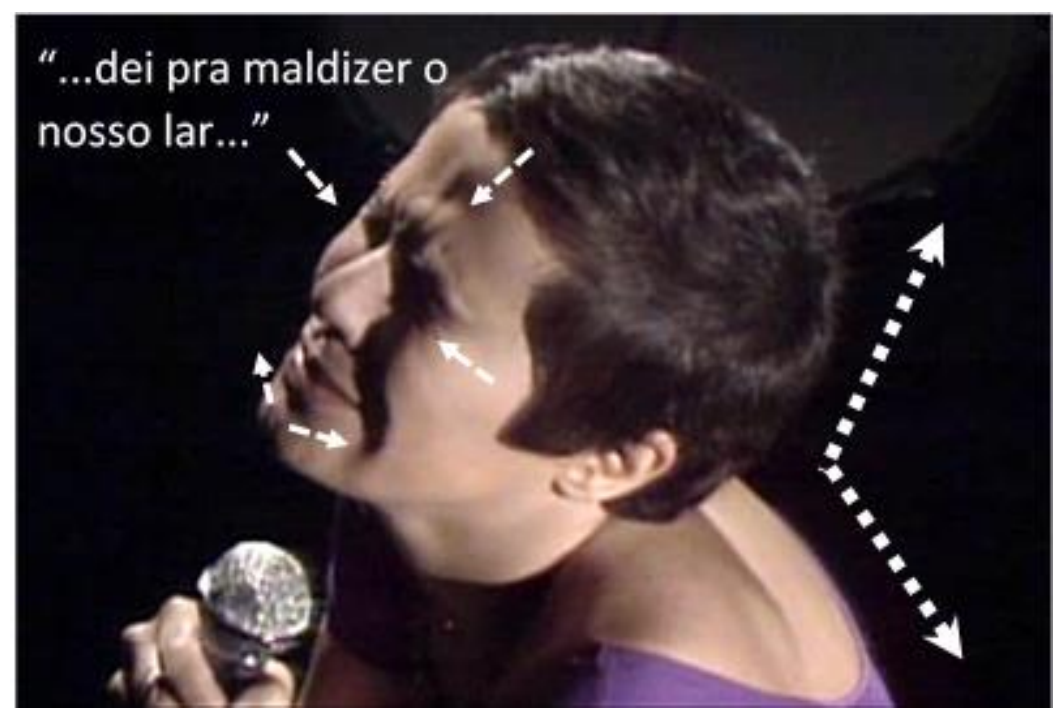

Figure 5 - A single-frame MaPA of sadness (at [2:24]) in Elis Regina's facial expression reflecting the lyrics by Chico Buarque: frown in the center of forehead, tight eyes, tight mouth, commissures stretched sideways, head tilted back and spine losing the upright posture. 
At [2:24], at the beginning of Section B2 (Figure 5), with the head tilting back and the spine losing the upright posture, Elis presses her lips against each other and stretches the commissures sideways, closes and tightens her eyes and frowns the center of her forehead. This occurs right after she sings “...dei pra maldizer o nosso lar..." ["... I began to curse our home ..."], which I interpret as a clear sign of the basic emotion of sadness (Ekman and Friesen, 2003, Figures 51, 52 and 60), and also of guilt because, in impotence, she attacked the most sacred thing: "our home", says the lyrics.

At [2:30], just before the climax in Section B2 (Figure 6), with the microphone firmly held in her right hand, with the mouth commissures slightly lowered and closed eyes, Elis raises her head, correcting the spine position to a more upright posture. Then, she freezes her movements, impassive. This posture of apparent security and control of the situation is highlighted by the effect of the scenic front light coming from the ceiling. Without singing, Elis remains in this silent position for a moment, a musical rest which occurs between two sung passages "...pra sujar teu nome, te humilhar" ["... to soil your name, to humiliate you"] and "...e me vingar a qualquer preço..." ["... and take revenge at any cost ..."]. The facial expression reflects the words of the poetry and sends clear signs of the basic emotion of contempt (Figures 1, 2 and 3 of Ekman and Friesen, 1986, p.161163). This basic emotion commonly rises to compound/complex emotions ( $\mathrm{Du}$, Tao and Martinez, 2014) or affects (Russell, 1980) that involve a reaction to humiliation by means of arrogance (the looking down one's nose) and revenge ("... to humiliate you ...", says the lyrics).

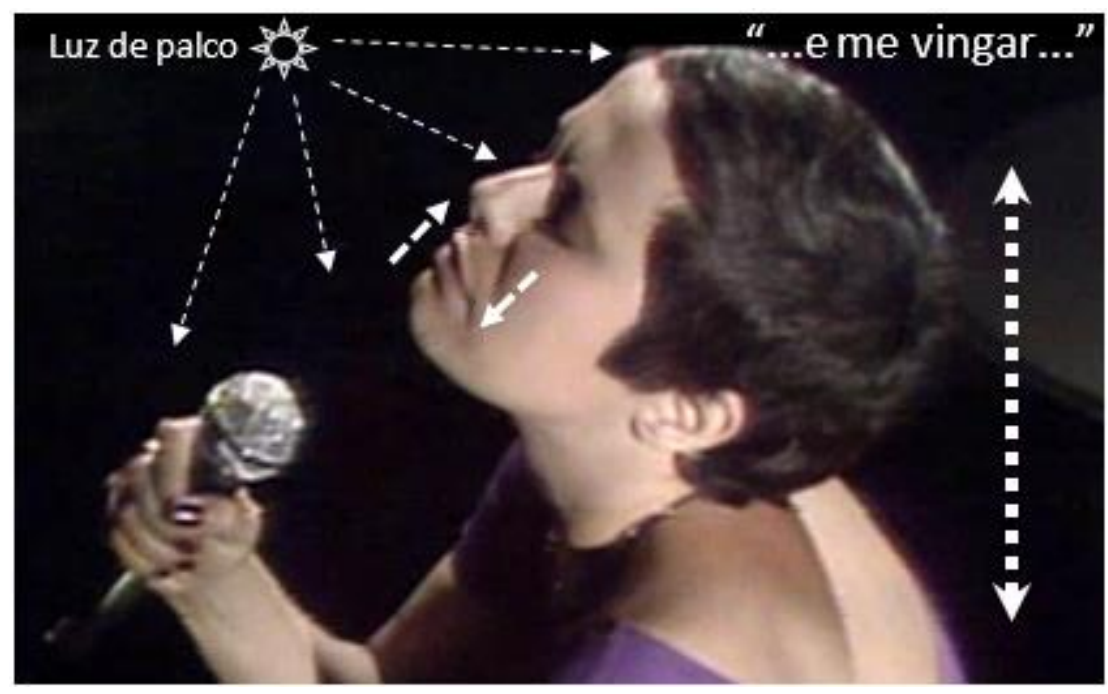

Figure 6 - A single-frame $\mathrm{MaPA}$ at [2:30]: expression of contempt/arrogance/vengeance in Elis Regina's performance in "Atrás da porta" by Chico Buarque: mouth commissures slightly lowered, looking down her nose and eyes closed impassively under the front stage light. 
Using two or more frames with arrows to indicate directions, a MaPA can retrieve the general idea of movements and facial expressions from the images of a video (Figure 7). Let us analyze the video of "Ladeira da Preguiça" ["Lazines Slope"], the third track of the DVD "Elis Regina: MPB Especial 1973" (Regina, Gil and Faro, 1973), a song with music and lyrics by Gilberto Gil, available at: www.youtube.com/watch? $v=g N X z 5 f l g W h Q$ (between [2:00] and [2:49]).

In the Coda, Elis Regina embodies the nonchalant air suggested by the lyrics in "...esta é a Ladeira da Preguiça...", ["... this is the Slope of Laziness ..."], which Gil remembers being from "...do tempo em que se amarrava cachorro com linguiça" ["... from the time when people used to tie a dog with sausage"]. The side-by-side combination of the two selected photograms suggests laziness in the rotation of the singer's neck, the tranquility and relaxation in the closed eyes and the expression of happiness in the smiley mouth.
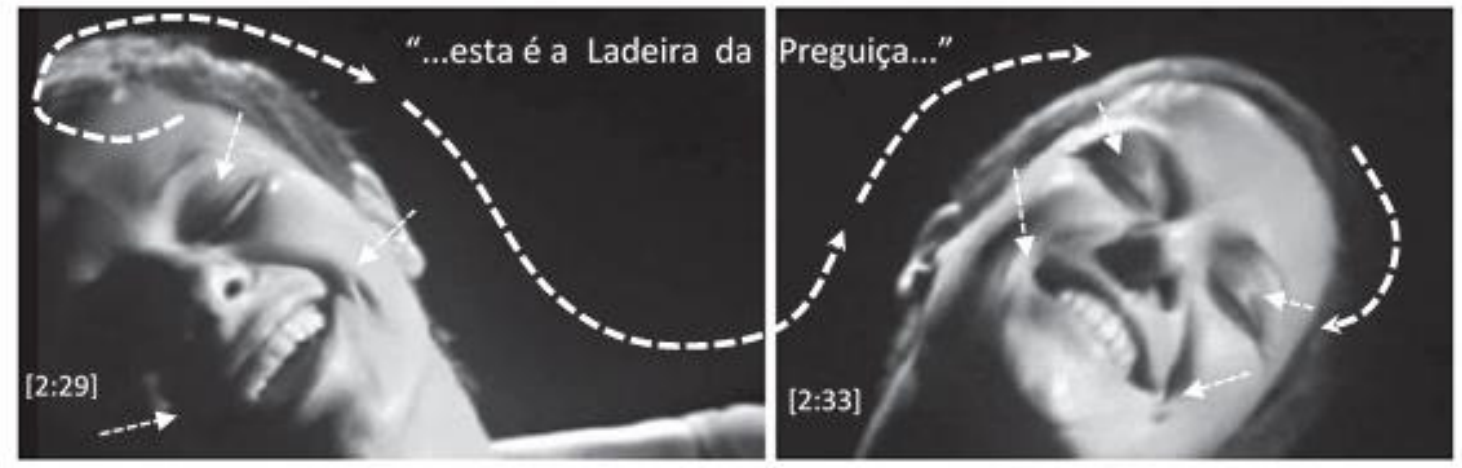

Figure 7 - A two-photogram $M a P A$ with timing information, facial expressions and head movement in Elis Regina's performance in the Coda of the Ladeira da preguiça video.

As it happened in Elis's Atrás da porta video, the naturalness of gestures of Elis Regina in the video of Ladeira da preguiça apparently suggests Director Fernando Faro recorded a spontaneous performance. However, Elis's perfectionism was notorious, as well as her predilection for long rehearsals and an obsessive attention to every scenic detail in performance practices "inherited" during her sojourn with Lennie Dale, whose Broadway rigor she took to the preparation of her shows (Borém and Taglianetti, 2014th, p42-43). These traits and especially a comparison of different recordings of the same song over the years, underlay the hypothesis of great and scrupulous planning for the integration of text, music and images. This is confirmed in the automation and repetition of body movement details (trunk, limbs, head and facial expressions), interaction with props, staging and lighting (BORÉM and Taglianetti, 2014b, p.60-61). But, as this performance by Elis is not completely controlled, and also includes improvisatory elements, I call this realization a quasi-spontaneous performance (an intermediate category in the continuum whose extremes are 
what I call spontaneous performance and non-spontaneous performance, as they will be demonstrated ahead.

The essence of a musical performance as a whole may be summarized by a simplified MaPA consisting of a few selected images from a video to represent its content through the main phases of its expressive process. In the song "Me deixas louca" ["You Drive me Crazy"] (by Mexican composer Armando Manzanero, with lyrics in Portuguese by Paulo Coelho), the arrangement sung by Elis Regina follows the forma Intro - $A-A^{\prime}-B$ - Interlude 1 - $B^{\prime}$ - Interlude 2 Coda (Perotti and Borém, 2016, p.24). Bodily speaking, Elis Regina performs this arrangement according to a seduction process between two lovers: herself and an imaginary partner. This process can be simplified into four consecutive phases: flirting, caressing, orgasm and relaxation. It describes an arch-like shape that can be imagined in the quadrants of Russell's Circumplex Model of Affects (p.1980, p.1174). The positive affects on $\mathrm{x}$-axis (as seduction, love and sex in this context) interact with negative values that grow and, then, decrease in the y-axis (serenity followed of excitement and, then, relaxation). The two medial stages of this process (fondling and orgasm) are repeated in the musical form, repetition which can be seen as an allusion to the "female multiple orgasm" symbol. Thus, it is possible to draw four frames (Figure $8 \mathrm{a}, 8 \mathrm{~b}, 8 \mathrm{c}$ and $8 \mathrm{~d}$ ) from four formal parts of the arrangement - Intro (seduction), Section A (fondling), Interlude 1 (orgasm) and Coda (relaxation) to appreciate as Elis Regina builds her performance in this video (Regina, Manzanero, Coelho and Oliveira, 2006).

Figure 8a shows the exact head rotation moment that shows the singer's seductive looking toward the viewer, with suggestive contractions of half-closed eyes and lips pressed against each other. Figure $8 \mathrm{~b}$ highlights the singer's position with hands tucked to her chest, left shoulder up and a head movement, suggesting reactions to her imaginary partner's caresses that would be embracing her. The frame of Figure 8c was selected precisely to suggest Elis's energetic and "involuntary" movements of hands and head just before reaching the orgasm. Finally, Figure $8 \mathrm{~d}$ shows a frame taken from the final scene of the video clip and illustrates the relaxation after orgasm, with the camera closing in the singer's arm extended upwards. The hand no longer has the appropriate tone to hold the microphone, which is pointing now to the opposite direction of her mouth, which no longer sings. 

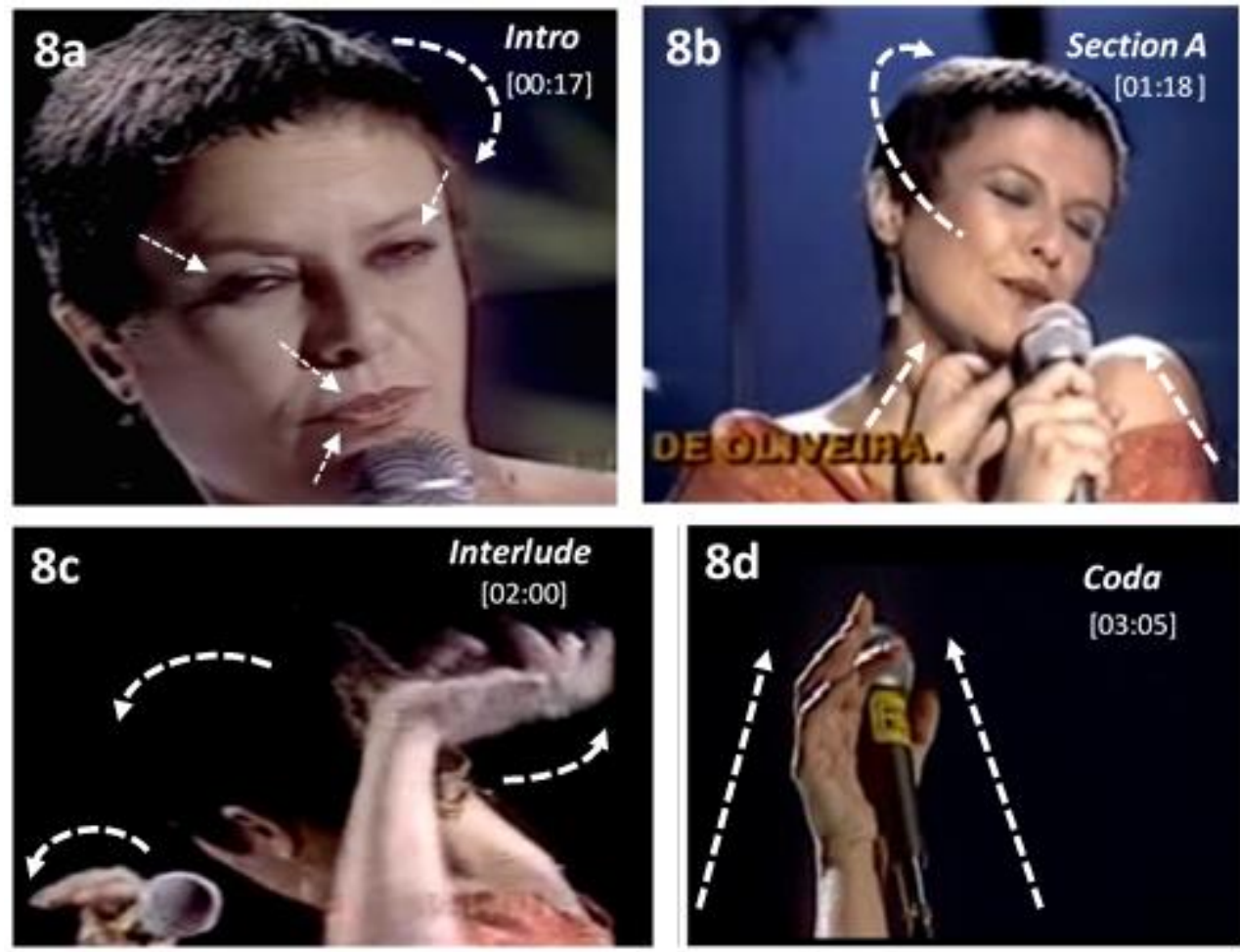

Figure $\mathbf{8 a} / \mathbf{8 b} / \mathbf{8} \mathbf{c} / \mathbf{8 d}$ - A four-frame $M a P A$ summarizing the corporal performance by Elis Regina in the song "Me deixas louca" (Regina, Manzanero, Coelho and Oliveira, 2006) according to a seduction process: (1) flirting, (2) fondling (3) orgasm and (4) relaxation.

If the three MaPAs consisting of a single frame each (Figures 4, 5 and 6 above) reveal punctual elements of Elis Regina's interpretation in Atrás da Porta, a more complete $M a P A$ gathering these and several other frames of this realization may reveal analytical data on a more general level and point great coherence and unity in the performance as a whole. For example, it may reveal the complex transition between the various feelings, triggered by words in the lyrics that characterize the Activation Contours. Moreover, it shows the relationship between interpretation and musical form, such as those driven by events described in the lyrics and expressed mainly in the face. For example, this integration plays the role of preparing the anguish climaxes of both Section B1 and Section B2. Finally, if we organize this sequential set of photograms to represent the song's interpretative Chunks, with its main Activation Contours, Sync Points, elements of its Dynamics and Kinematics, we can build a detailed MaPA that reveals the process of building a performance of the musical form based on relationships among the lyrics context, vocal expression, face expressions and larger gestures.

Thus, Figure 9 illustrates a fairly complete $M a P A$ of Elis Regina in the Atrás da Porta video, which arrangement follows the Intro - $A$ - B1 - B2 - Coda scheme. The MaPA of Elis's realization contains two parallel Chunks with similar Activation Contours. One can observe, in each of these, her head occupying 
scenically the low plan, then the high plan, and then back to the low plan of her Kinesfera (Laban, 1978, p.63-64, 73), matching the formal sections of Chunk 1 and Chunk2, respectively. There are also identical Sync Points (the face down in the dim light, the face up in frontal stage light and the piano subito after the climax with the head high in open light), Kinematics (mouth movements and facial expressions) and similar Dynamics that increase followed by a surprise (intensity of facial expressions and climax with a crescendo followed by a forte-piano subito).

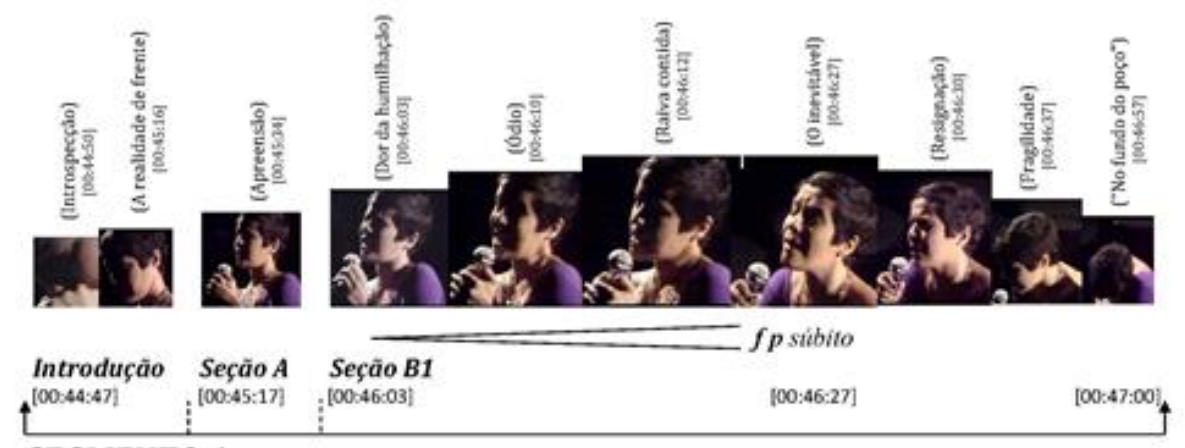

SEGMENTO 1

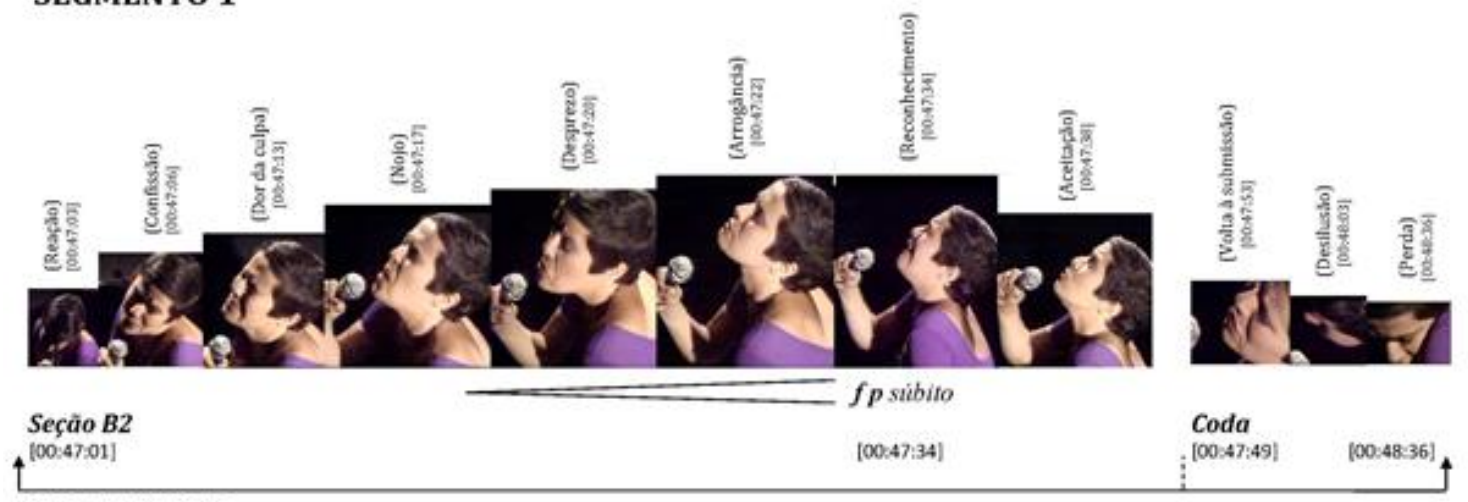

SEGMENTO 2

Figure 9 - A detailed MaPA of Elis Regina's performance in Atrás da porta (Regina, Buarque, Hime and Oliveira, 1973) with 21 photograms evidenceing two sequences of facial expressions which divide the arrangement's form in two parallel archlike Chunks with similar Activation Contours, identical Sync Points and similar Dynamics and Kinematics.

The quote "The most refined ears swear Elis never repeated the same interpretation, always letting loose her privileged voice for improvisations" (Albin, 2003, p.324) expresses well the myth and confusion surrounding the spontaneity of Elis Regina's performances. In fact, all photograms above were taken from music videos in which I identify quasi-spontaneous performances. In other words, there is previous planning and great stage-music control in both rehearsals (on the part of the performer) and in the recording sessions (on the part of the video director and also the performer). There is the choice of the best takes, the best angles by the camera operators, the best light effects etc. But there is also a certain degree of freedom in performance, typical of live music. There is 
the fluidly "pouring" rhythm realization ("métrica derramada", or "malleable meter"; Ulhôa, 1999), there is the inclusion of spontaneous vocal or instrumental effects and there are small asynchronies and "errors" that characterize the performance as human. On both extremes of the quasi-spontaneous performance continuum, I see the spontaneous performance and the non-spontaneous performance, both of which I illustrate with two MaPAs: one of Elis Regina and other of Caetano Veloso, respectively.

Spontaneous performance, in general, is not spontaneous throughout its duration, as it may include prior planning of both performer and video director. However, it contains excerpts from the music or theatrical realization that escape the control of the artist, revealing "errors" or unplanned events that, very often, are incorporated into the performance. Also very often, these excerpts reveal quite significant content to the context of the music realization. I resort again to Elis Regina's performance of Atrás da porta, but this time using a live recording without any editing. Over decades, Elis Regina kept in the performances of this song, the same choreography for its basic head movements. Since her first important recording of this song, still with black and white photo technology, directed by Fernando Faro, going through the recording directed by Roberto de Oliveira (discussed above) until the last one, directed by Daniel Filho, her Atrás da porta performances were based on two consecutive emotional arcs (described above), outlined by the wavy down-up-down-up-down head (which becomes more vivid under the stage lighting that results in a dark-light-dark-light-dark sequence). This theatrical effect, in turn, emphasizes the musical form and construction the two climaxes yielded by the melodic line of Francis Hime and lyrics by Chico Buarque (see Figure 9 above). Seven years after the recording directed by Roberto de Oliveira, Elis repeated her general plan of performance in the recording made by Daniel Filho (Borém and Taglianetti, 2014b, p.66), which was included in the Grande Nomes [Great Names] series of Brazilian TV Rede Globo (Regina, Buarque, Hime and Filho, 1980) and released a little more than a year before her tragic death (Ferreira, 2005). ${ }^{11}$ Elis repeats with extreme precision a crucial Sync Point of her performance in the recording made seven years earlier. At [1:32], in the decrescendo after the climax of Section B1, she performs the same and delicate rhythmic convention on the word "pé" ["foot"] in the phrase "...Nos teus pés, ao pé da cama..." ["... Down at your feet, by the bedpost ..."]. Synchronously with all the musicians of the band, Elis falls into the note F\#3 after a descending glissando of an octave, coming from a long note, the F\#4 (REGINA, 2014, p.72, m.31). So far, nothing spontaneous.

${ }^{11}$ This video of "Atrás da posta" aired on TV on October 3, 1980 by Rede Globo, in the "Elis Regina Carvalho Costa" program. Elis died on January 19, 1982. 
But there are several imagetic and auditory clues in this video pointing that the usual high control characteristic of Elis surrendered to the spontaneity of the emotions she was immersed in her personal life, ${ }^{12}$ as shown in the MaPA of Figure 10. In the opening scene, the zoom in over the small figure of Elis sitting on a high stool enhances the psychological fragility of a singer in the final phase of her life. There, Elis remains 22 seconds (from [0:12] to [0:34]) without showing her face to the audience; restless, she shakes her feet (at [0:16]) as if seeking comfort to start the song. Then, for 29 seconds (from [0:46] to [1:15]), Elis sings hiding her face with her left hand, her gestures and voice are clearly taken by an emotion that she could not control. Not long after the beginning, at [0:24], the A note in the syllable "lhas" in the phrase "Quando o-lhas-te bem..." ["When you really stared..."] comes out low, out of tune, almost an A flat. Because of the imminence of tears, her singing can hardly be heard. At [0:49] several singing flaws are noticeable in "... e me arrastei ..." ["... and I dragged myself..."]. Then, to pronounce "...e duvidei..." ["... and I doubted ..."] at [0:59], the syllable "dei" is released with great effort and with a most intubated timbre.

Physiologically, the difficulty of Elis in articulating words and keep a constant flow of the air column several times in this live recording, is related to the increased flow of blood and oxygen in the vocal tract, generated by the stress of grief. Therefore, there is an involuntary expansion of the glottis in order to pass more air. The dry swallowing (typical of the crying process) or the articulation of consonants (demanding more contraction of the vocal cords) act strongly in opposition to the expansion of the glottis, creating a tension that is felt as a "lump" (or a "bulge") in the throat (Shere, 2013). This is the cause for Elis Regina's technical problems observed in this analysis. Continuing, when she sings "...e te arranhei..." ["... and I clawed you ..."] at [1:11], Elis no longer expresses the same anger in the face as in the singing of the previous recordings, but a great weakness in her voice, fragmented, and with a facial expression of defeat. At

${ }^{12}$ Elis Regina's ex-husband César Camargo Mariano reports another experience of Elis crying while singing "Atrás da porta" in a rehearsal (Pinheiro, 2015): "The first show I did with Elis, in 1971 at the Teatro da Praia in Rio de Janeiro, had the direction of Ronaldo Bôscoli, who had broke up with [Elis] ... in the middle of a rehearsal, I suspected of an out of tune chord, I called Helio [Delmiro, the guitarist] and told him, "... at this point, Elis often holds over the note, and we need to find a solution for her to sing that way." The conversation lasted all afternoon and an impatient Ronaldo [Bôscoli], pacing back and forth, came to me to complain: "Cesar, stop it! What an obsession! You're all afternoon into this chord [...] I told him: '... the guy sitting in the back [of the audience], when he hears that perfect chord, he can't tell, but this is the chord that will give him goose bumps. This chord, the way Helinho [Delmiro] and I are thinking, will make Elis feel comfortable in the interpretation and this excitement will reach the public in the heart... we fixed everything and called Elis to go through the music. When the time of the chord came up, which happens in the section 'Dei pra mal dizer o nosso lar...' [I began to curse our home ...], she sang the words, her eyes filled with tears and she could not stop crying." 
[1:42], the central vowel " $e$ " in the articulation of the word "tapete", ["carpet"], is repeated fragmentarily, similar to the effect of a tremolo in bowed string instruments. This technical problem of voice emission continues in "...no tapete atrás da porta... reclamei..." ["... on the carpet behind the door ... I complained ..."], until it is very evident in the utterance of the word "baixinho" ["quietly"] as if she was stuttering. The stool, which functions as a prop to the show's more intimate ballads, becomes a crutch at [2:54], with Elis leaning her body down over it, drained from a performance that seems to be very exhausting. At [3:14] Elis sticks out her tongue, quickly, as if seeking for saliva to wet her her lips, probably due to sensation of dry mouth. In the Coda (at [2:57]), with her vocal tract totally overcome with emotion, the planned boca chiusa unison with the right hand piano does not work. Elis's immediate solution is trying to sing with her mouth open, and even then, the result is almost inaudible. Finally, as with the warmth of the audience's applause, she marks the end of the performance pressing her eyelids hard and quickly, letting drip tears of real crying at [3:24]. Among the 16 emotions linked to secretomotor alterations in the autonomic nervous system listed by Levenson (2014, p.109), sadness is the only one that produces tears. Thus, this is another sign of Elis's spontaneity in this performance.

But the uncontrolled sadness and crying is also evident at other levels; ${ }^{13}$ which explains the fact that, during the nearly 4-minute video length, Elis's avoids eye contact with the audience. She opens her eyes only once and briefly (for only 3 seconds between [2:08] and [2:11]), and only opens them again when she is no longer singing, after the end of the song at [3:26]. If we understand the difficulties of Elis in this performance using LABAN's concept of Effort and its factors (1978, p.57, 73, 76, 79, 86 and 126), we can describe her movements as centered in the head and trunk, in a very confined Space of her Kinesfera (Laban, 1978, p.69). Its unfolding happens in a sustained Time, weak and tense as far as its Weight, and with a chunky Flow. But there is nothing derogatory about it. On the contrary, her humanity was probably the reason why this video became one of her most exciting performances, "... an illuminated instant [...] anthological moments of the Brazilian TV" (FERREIRA, 2005).

${ }^{13}$ Rottenberg et al (2002, p.302) describes: "Crying is a secretomotor response defined by the shedding of tears from lacrimal structures. Crying while sad is often accompanied by grimacing and other facial expressions of sadness, by vocalizations, and by the convulsive inhalation and exhalation of air." 


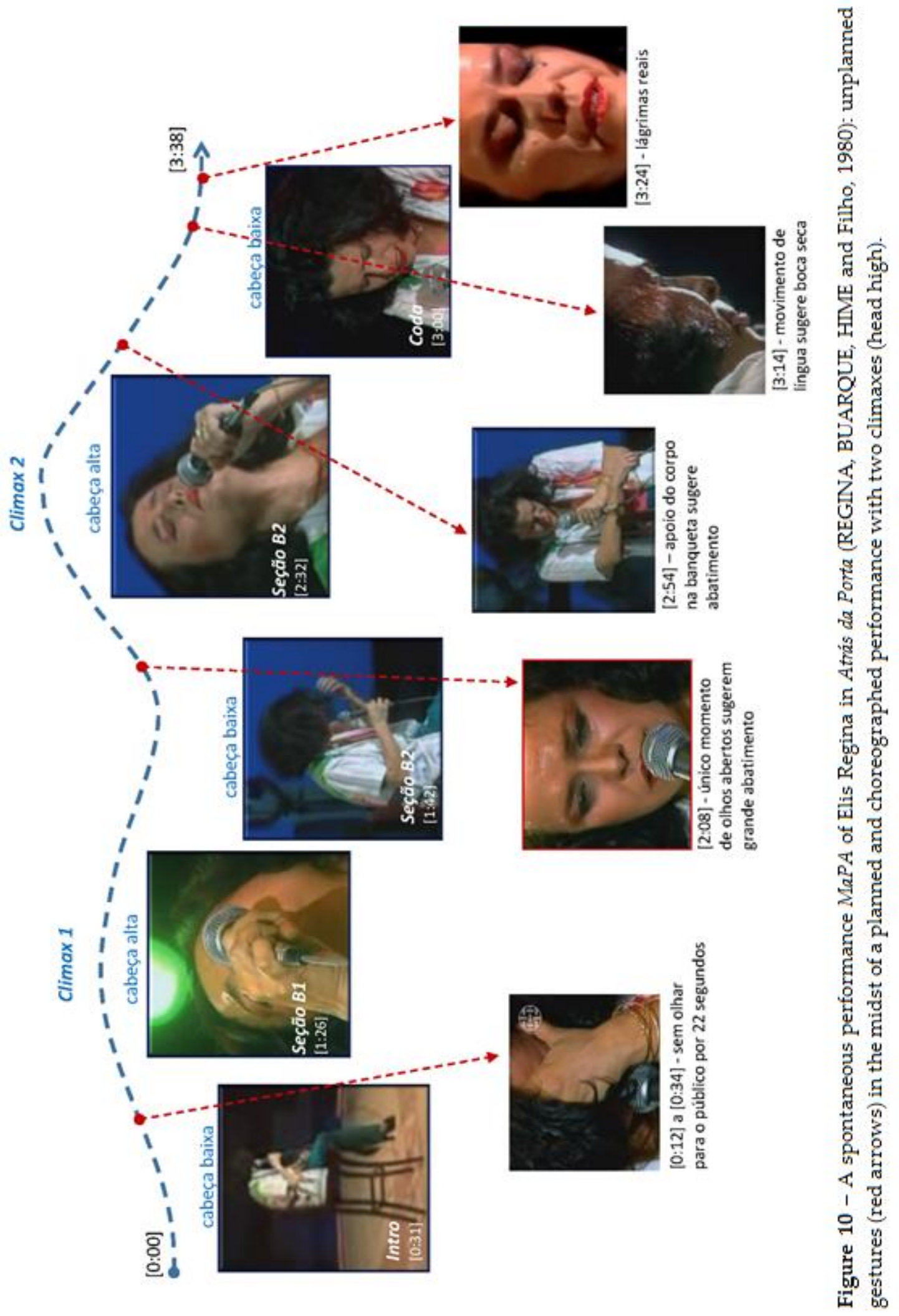


The non-spontaneous performance largely embodies and emphasizes cinema and video clip aesthetics with a vast array of experimental or consolidated imagetic languages. Therefore, it is not intended to convey the naturalness of live music performances. It calls for a much greater interference of the art director (or video photographer) and usually requires a creative work of pre-recorded images manipulation, leaving apparent traces of his/her "compositional" work superimposed on the music interpretation. The recording of the music is not live and, generally, the film director select an audio track from a CD, MP3 etc. to work with. In addition to being heard and appreciated by the viewer, the audio track is strategically used by the artists as a playback to choreograph gestures, production of sounds and lip-sync. The non-spontaneous performance involves many takes of the same scene, taken from different angles with multiple cameras, inclusion of special effects, cuts and a good deal of film editing. The visual appeal of video clips has become so strong in commercial music that the release of a new CD (or newer audio formats) is almost always accompanied by a multimidiatic version of a track chosen to be a hit. These popular music video clips (but also, to a lesser extent, classical music video clips) involve expensive productions, sponsored by large companies such as Vevo, to be massively publicized and become the mainstay of a release.

In this way, the music video of A Bossa Nova é foda by Caetano Veloso, directed by video makers Fernando Young and Tonho Quinta-feira (Veloso, YOUNG and Quinta-feira, 2013; in www.youtube.com/watch?v=orPhkLpX3ps) was recorded and edited with scenes performed in studio, without musical instruments. Add to this the unique trace of this Brazilian intellectual-composersinger to hone in the use of slangs, figures of speech, riddles, puns, subliminal messages and historical sociocultural contexts. This served as a pretext for the directors to create relationships beyond the obvious and immediate meanings (Borém, 2016). In this type of music video, spontaneity is not even considered. For example, you can appreciate 11 seconds (from [0:14] to [0:25]) of a closedmouth singer, although his voice can be heard in the passage "... quem terá tido esta fazenda de areais [...] uns restos de rabada..." ["...who would have owned this farm of sands [...] leftovers of an oxtail dish..."]. The high degree of interference of the directors in the film editing results in a video segmentation that clearly outlines the sections of the musical form, generates a large number of Sync Points between images and sounds, and precisely aligns Activation Contours with Kinematics and Dynamics.

The result is a profusion of selected and edited images that reiterates and interacts with the lyrics' sophistication and encodings, interactions that are planned and manufactured to illustrate, dialogue, counteract or even subvert the senses of the audio. The title and lyrics of the song contains Caetano's intention to challenge a consolidated national symbol, proposing "... a picture of Bossa 
Nova as a historical and aggressive aesthetical gesture, not the cliché of that soft sweet thing... "(Veloso, 2012, [1:27-1:43]). Therefore, a MaPA that seeks to represent the rich universe of this video needs many frames to tell its story (Figure 11). The editing of photograms in movement allows the video director to act in a manner similar to a music composer who chooses and develops motifs, contrast themselves and replicates them to make sense of the musical form. Another motivation for visual emphasis of this non-spontaneous performance was inspired by the planning of the arrangement itself, which juxtaposes musical genres (blues, rock, bossa and jazz-waltz) by means of very well defined ways (instrumentation, grooves, metrics and text-music relationships) which do not mix or hybridize but characterize the friction of musicalities proposed by Piedade (2003). In the MaPA of "A Bossa Nova é foda", the motif of the singer's face framed and immobilize by several hands marks the beginning of the formal sections of blues predominantly (groove and instrumentation). More aggressive images the hand gagging the mouth of the singer, the obscene gesture with the middle finger, the MMA (Mixed Martial Arts) strikes, challenging poses and the fire are reserved for the chorus of the song, which is associated with rock'n roll. Spiritual allusions (the Hinduism icon suggested by the God with various arms choreographed by Caetano and his musicians at [1:09], the Brazilian Candomblé trance index suggested by Caetano's dance and turned eyes at [1:25])) are superimposed to the softness of the bossa nova genre and lyrics honoring the poet-musicians Tom Jobim and Vinicius de Morais. Another soft genre, the instrumental jazz-waltz, without words to be an instrumental interlude, receives a similar imagetic treatment (the dripping water, the human aura and the Catholic faith, as suggested by the icon of a scapular in Caetano's chest, revealed among the frame of the musicians' arms at [2:47]).

A MaPA allows the view of analytical relations at local and more general levels. The use of color-coded signs on the map, a strategy made more viable economically now with the predominance of virtual publication, facilitates and optimizes the representation and reading of these analytical elements (Figure 11). For example, selected video images may reflect the contrast and provocations that swing between male and female stereotypes, which is central to Caetano's creative motivation in "A Bossa Nova é foda". Below the photogram assemblage of this $M a P A$, one can appreciate male segments, or Chunks $I, I^{\prime}, I^{\prime \prime}$ and $I^{\prime \prime \prime}$ (represented by the blues genre, in dark blue color; and the rock genre, in purple color) and female segments, or Chunks I and III (the bossa genre, in light blue color; and the jazz-waltz genre, in pink color), its internal formal sections (Intro, $A 1, A 2, A 3, A 4, B, C$, Chorus and Coda) with their respective timings and their associations with these musical genres. The timings noted in bold red with increasing values $\left(8^{\prime \prime}, 16^{\prime \prime}, 38^{\prime \prime}\right.$ and $\left.45^{\prime \prime}\right)$ show the gradual predominance of the 
rock genre, which explains, temporally, the intention of the song title. ${ }^{14}$ Going through the Chunks of this map, it is possible to appreciate a dialectics of opposite musical materials (blues/rock versus bossa/jazz-waltz) well separated from each other (hence their non-hybridization). Finally, we come to a "mediation" of this polarization through a hierarchic coexistence (with male predominance) without loss of identity (the female pole), which occurs in Chunks II and III. At the same time, at local levels, it is possible to visualize indexes representing the feminine as a challenging power, such as the index of the trickling water moving up vertically, against gravity (from [3:25] to [4:08], in the Coda).

The use of photograms containing links to video and audio files (a feature that is being implemented worldwide in scientific publications) is another possibility to illustrate the presentation of analytical data in MaPAs and EdiPAs. This allows the reader to follow aurally and visually (with moving images) the analysis presented in small, medium and large excerpts.

${ }^{14}$ Among the three meanings of the slang "fuck" presented in the online Aurélio portuguese dictionary (Buarque de Holanda, 2015), Caetano uses the more recent meaning, i.e., the meaning "the best", especially in male radical sport circles such as MMA (Mixed Martial Arts). 


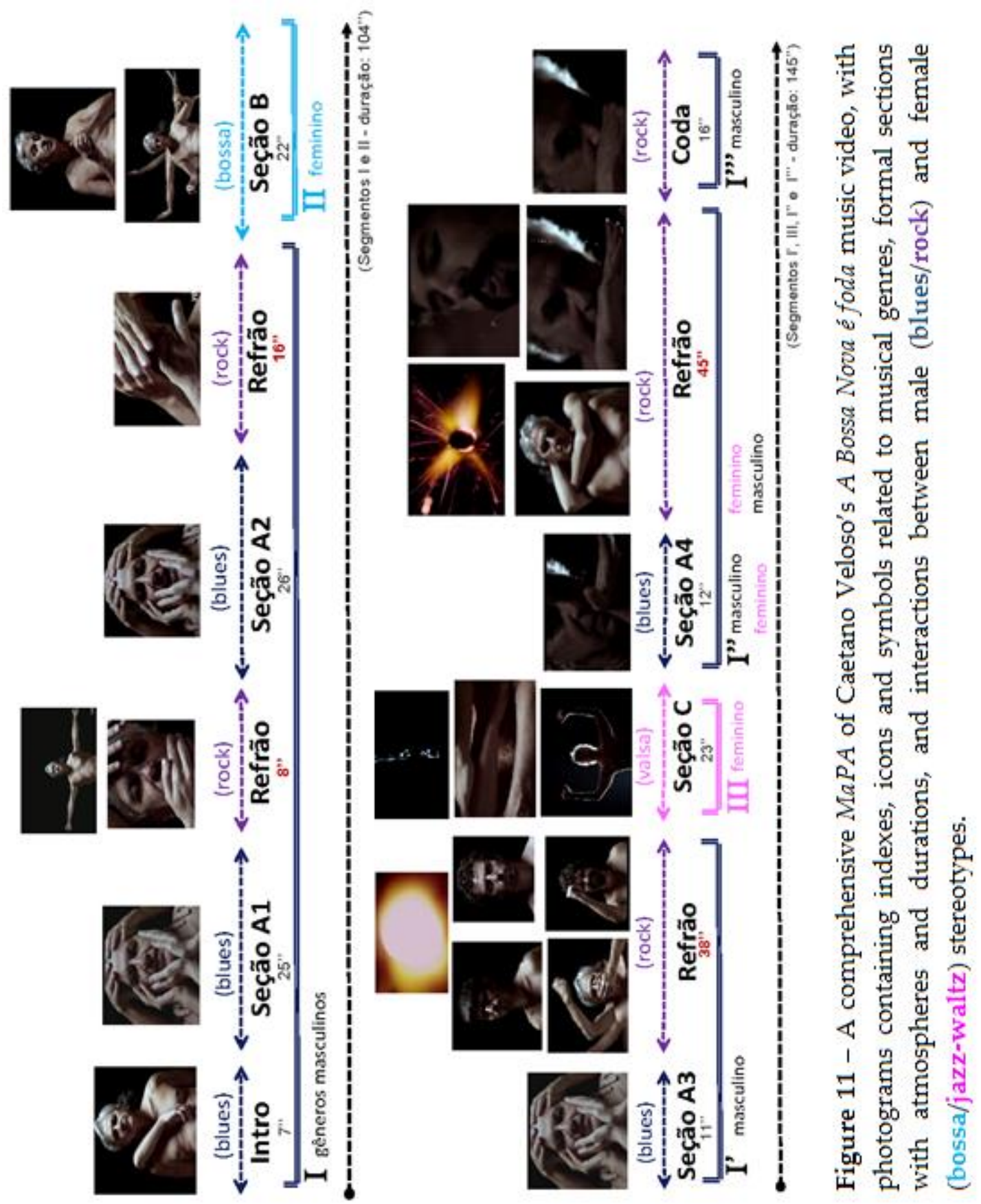




\section{3 - The construction of an EdiPA (Edition of Audiovisual Performance)}

$E \operatorname{diPA}$ is a music score on which are placed $M a P A$ photograms, concise textual information and graphic signs indicating relevant elements of analysis to facilitate the understanding of a performance presented in a music video. Figure $2 \mathrm{a} / 2 \mathrm{~b}$ at the beginning of this article is a simple EdiPA. It contains the basic element of its construction: the musical transcription from an audiovisual source that is not available or documented in the traditional music literature (such as books and scores). Traditional music scores can also be used to prepare an EdiPA, adding textual information of performance practices that may reveal technical or stylistic data of a composition or its interpretation. Figure 12 shows an EdiPA (Ribeiro, Borém and Rocha, 2015; Ribeiro and Borém, 2015; Ribeiro and Borém, 2012) based on the printed score of the Andante from Concerto Op.3 by bassistcomposer-conductor Serge Koussevitzky (1985, p.5), aligned with a spectrogram of its 1929 historical recording (Koussevitzky and Luboshutz, 1929). This EdiPA indicates three performance practices: rubato, portamento and vibrato, which are essential for understanding the interpretation of the changing styles in classical music in the first half of the 20th century. The rule in tenths of seconds between the spectrogram and score shows precise timings of musical events, the subtle tempo variations due to rhythm realization (visually reflected in the distances between the musical notes), three types of portamento (initial, final and intermediate types) and the gradations of the vibrato parameters (amplitude, rate and continuity). The rule also allows to measure, for comparative purposes, the exact duration of each bar in the recorded performance (shown in red, for example, below the staff in $\mathrm{m} .4$ and $\mathrm{m} .8$ ). Other data could be extracted from the spectrogram, such as intensities, articulation of notes and timber aspects, expressed in the thickness of lines and nuances of color of the partials evidenced in the harmonic series. 


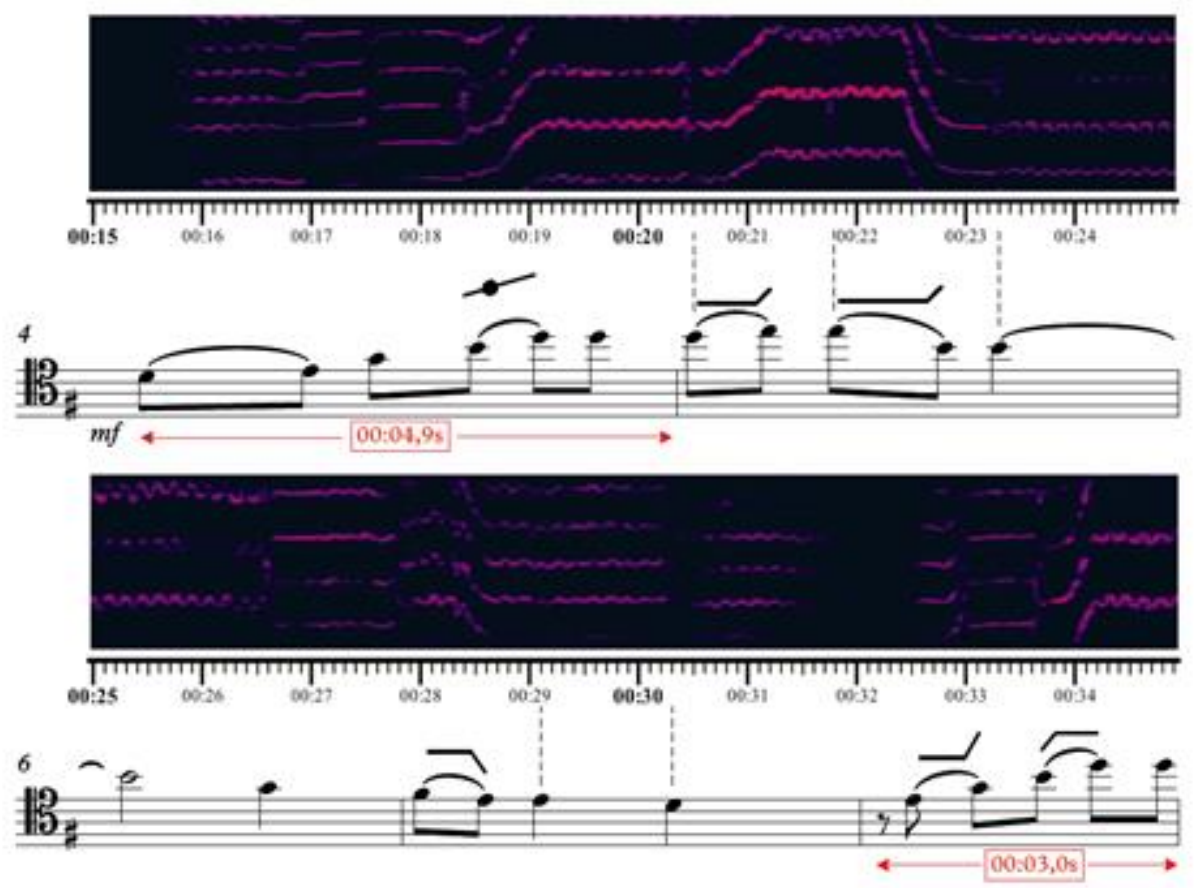

Figure 12 - An EdiPA of the historical 1929 recording of Concerto Op.3 by composerbassist Serge Koussevitzky, with indications of event timings, rubati, portamenti and vibrati (Ribeiro, Borém and Rocha, 2015).

The example above shows that an EdiPA can be constructed from the transcription of an audio recording (especially when the video is not available), and may bring audiovisual analytical elements that help to understand the composition and its performance. In another example, Figure 13 shows an EdiPA of an excerpt of Cannon, music for solo flute with extended techniques and electroacoustic sounds, composed and performed by Hermeto Pascoal (1977). In a spectrogram of this music (Borém and Freire, 2010, p.70; Pascoal, 2010, p.81, mm.31-33), it is possible to evaluate the techniques of humming and nasal humming, realized in the flute simultaneously with the traditional air blow, the result of which is a counterpoint with two opposing voices and, then, the realization of a unison (see bottom and middle parts of the music staff). The top part of the music staff shows a third stratum, which refers to the lines of prerecorded and manipulated sounds that have been superimposed to the flute and humming voices. 


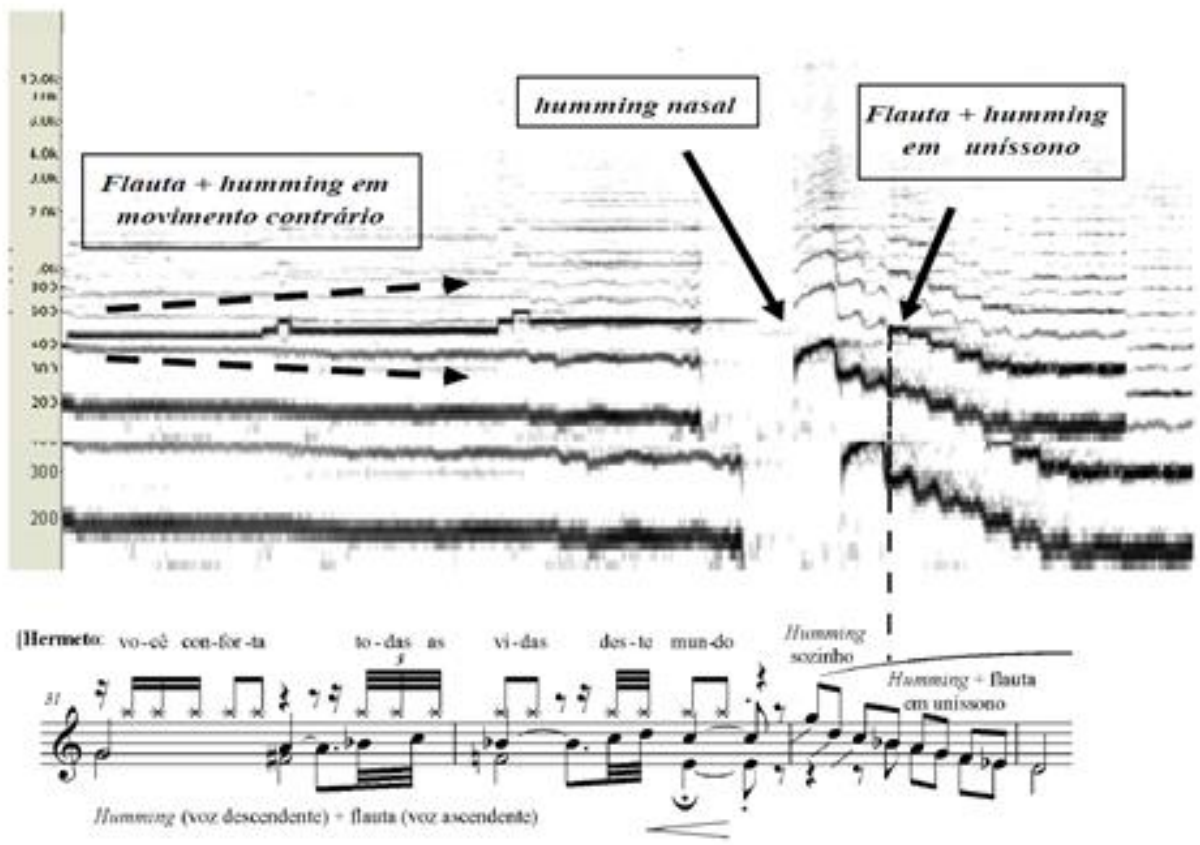

Figure 13 - An EdiPA pairing a spectrogram with its transcribed score: performance practices in Cannon, for flute and pre-recorded sounds, composed and performed by Hermeto Pascoal.
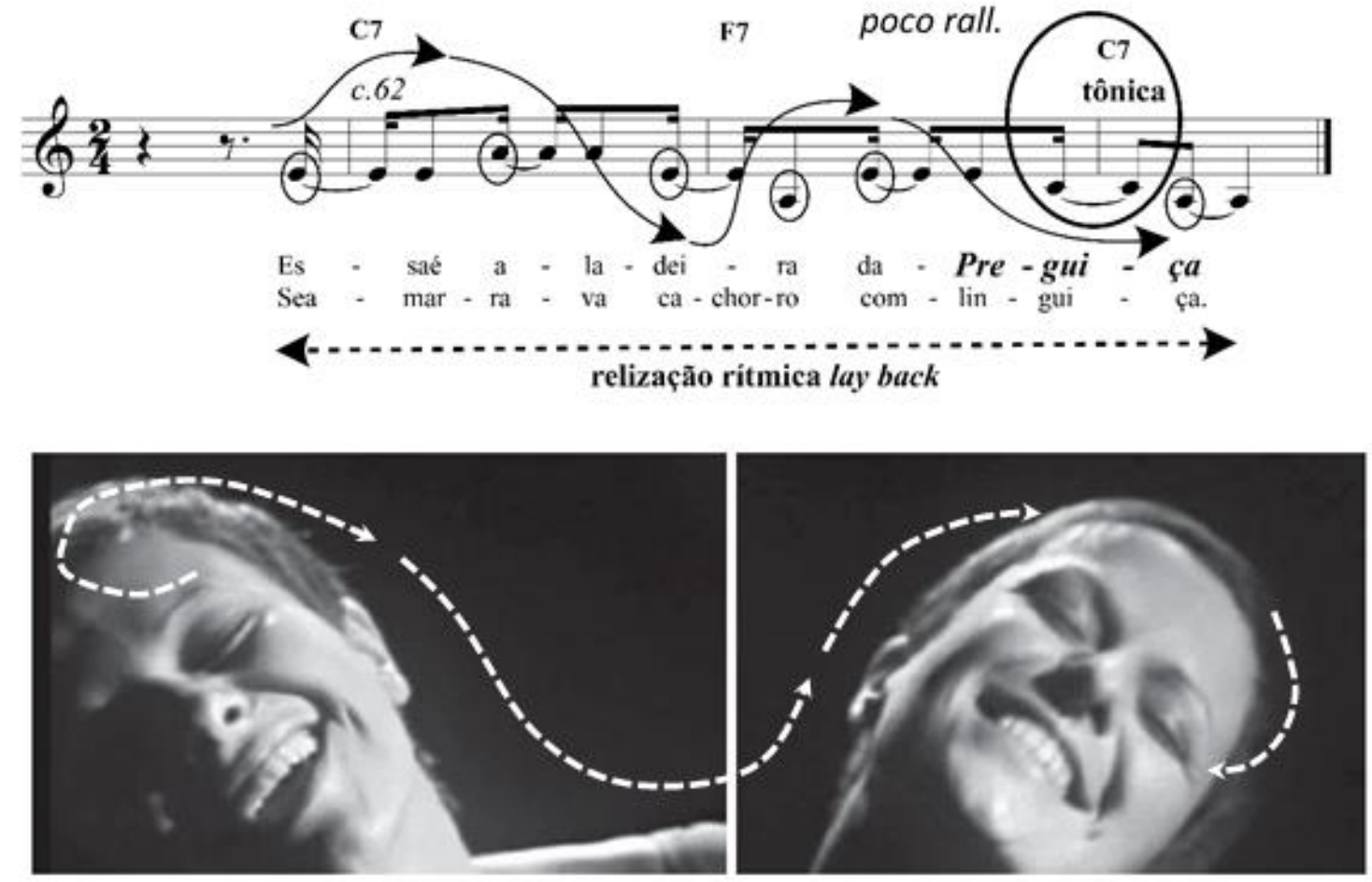

Figure 14 - An EdiPA of the Coda of "Ladeira da preguiça" ["Laziness of Slope"] showing audiovisual emphases in indexes contained in the lyrics and melody of Gilberto Gil incorporated into the stage gestures of Elis Regina. 
The relationships in the text-sound-image trinomial can be better appreciated in musical realization if, visually, we pair video photograms with the music score. The EdiPA in Figure 14 was based on the MaPA presented in Figure 7 (above) and reveals that the wavy head movement of Elis Regina and her lay back rhythm realization on Coda of "Ladeira da preguiça" ["The Laziness Slope"], intuitively or not, reflects both the wavy melodic line she is singing (in this case, transcribed from a previous lead sheet) and the lyrics of Gilberto Gil, an integration that generates a great visual emphasis, coherence and unity.

In popular music, musical notation is usually very simplified and hides relevant performance practices. In the interaction between musical genres explained before, Caetano draws on three vocal effects - yodel, ${ }^{15}$ fry $^{16}$ and falsetto - to underline atmospheres suggested by blues, rock and bossa in his song " $A$ Bossa Nova é foda" (see Figure 11 above). To make explicit the impact of these genres in the text-sound-image amalgamation, the three EdiPAs shown in Figure 15a/15b/15c bring: (1) selected photograms from the video; (2) musical transcriptions of excerpts from the music with melody and chords; (3) vocal effects with their locations, both in the music score and in the video with respective timings; (4) lyrics excerpts that inspired the vocal effects; and (5) colorcoded indications for music genres in the indications of the sections (blues, rock and bossa). In Figure 15a, the rural nature of the blues (and American folk music, by extension) is reminded in the lyrics ("...fazenda de areais..." ["...farm of sands..."]) and the yodelling that honors Bob Dylan's voice, "... o bardo judeu romântico de Minnesota ..." ["... the romantic Jewish bard from Minnesota ... "]. Visually, Caetano's admiration for Bob Dylan is expressed in his naughty half-

15 The yodel is a typical onomatopoeic singing style of rural areas in several countries, characterized by rapid and audible register exchange between head and chest voices or, from the point of view of phonoaudiology, between laryngeal mechanisms M1/M2 and M3 (Kob et al, 2011, p.362-363). It has become very popular in Tyrol due to its rugged geography, which favors reverberation and echos in its realization. It was used in classical music until the late 19th century, as in the song Il Viaggio a Rheim by Rossini (Wise, 2007, p.1). Today, it is very common in pop, country, Brazilian sertanejo music etc.; the rural environment to which the style refers to was humoursly approached by by Rita Lee in her "Tiroleite" ["Milk the cow"] song (Rita Lee, Arnaldo Baptista, Sergio Dias and Liminha) on the Polydor LP "Hoje é primeiro dia do resto de sua vida" ["Today is the first day of the rest of your life"] (Lee, 1972, track 7).

16 The fry (or creak or strohbass or crepitation or basal sound) is a singing style that became popular in genres like pop (in medium and high registers) and rock (such as rhythm \& blues, heavy metal and punk rock in the low register). It is produced in the laryngeal mechanism M0 (Kob et al, 2011, p.363, 366) and is characterized by the rapid opening and closing of the respiratory cycle (Cielo 2011, p.365-367).

16 The falsetto (or super high sounds; Cielo 2011, p.367; or head voice or loft register, WISE, 2007) is a singing style produced in laryngeal mechanism M2 (Kob et al, 2011, p.363), mainly by men in order to reach the soprano register, through the vibration of the vocal folds by incomplete apposition (Gurry, 2014, p.119). 
smile and slight lateral movement of the neck at [0:17]. In Figure 15b, the aggressive nature of rock appears in the male slang "...é foda..." ["...is fucking good..."], sung with the vocal effect of fry in the lowest voice register. At [2:15] the singer has the face immobilized by hands, as in a MMA fight (surprisingly, a favorite radical sport of Joao Gilberto, himself a Bossa Nova suave symbol). In Figure 15c, at [1:40], there is a sudden movement of the head and wrinkles on the forehead suggesting Caetano's basic emotion of surprise (Ekman and Friesen, 2003 Figures 9 and 10), but with a smoothness that alludes to the bossa. These indexes highlight the singing in falsetto that speaks of "... o tom de tudo comanda as ondas do mar..." ["... the tone of everything commands the ocean waves..."], a reference to Tom Jobim's name and his passion for Rio's coastline (as in the lyrics of his famous song Wave). The music staff of this transcript also reveals the sophisticated harmonic style of Bossa Nova (the major chord with major seventh, A7M) and Jobim's practice of repeating the same note in the melodic line, accompanied by a chromatic harmonic progression.
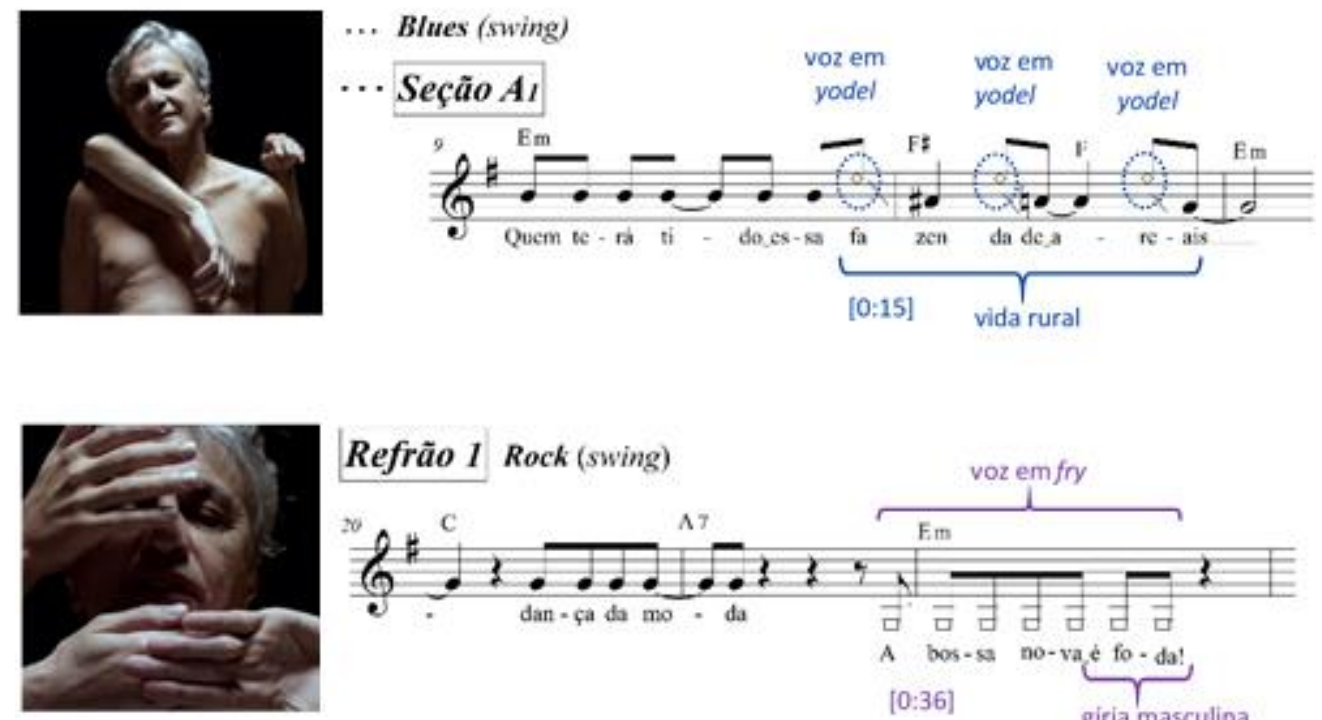

Refrão 1 Rock (swing)
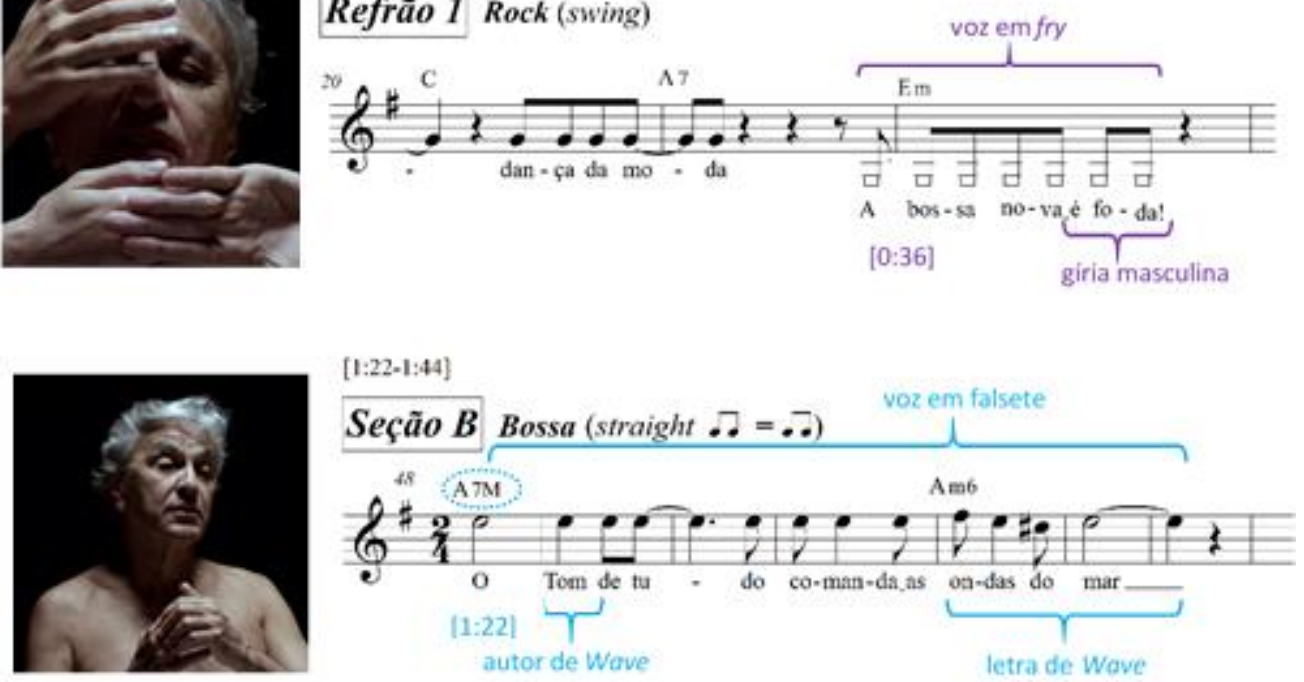

Figure 15a/15b/15c - Three EdiPAs with Caetano Veloso's vocal effects associated with the music genres (blues, rock and bossa), the lyrics, and the images of the "A Bossa Nova é foda" video. 
Finally, I present an EdiPA of a complete song. In addition to showing data of the analysis and synthesis processes, it provides a music score for the music realization containing stylistic features of the composer, the lyricist, the performer and the director of the video. Thus, Figure 16 brings the EdiPA's first page of "Atrás da porta", which is the result of a ten-hand artistic creation by singer Elis Regina, lyricist Chico Buarque, composer Francis Hime, songbook editor Almir Chediak and video director Roberto de Oliveira (Regina, Buarque, Hime, Chediak and Oliveira 2014). If, on the one hand, this score allows an analytical reading of the work, on the other it gives the performer a document from which he/she can emulate, diversify or contradict an earlier interpretation.

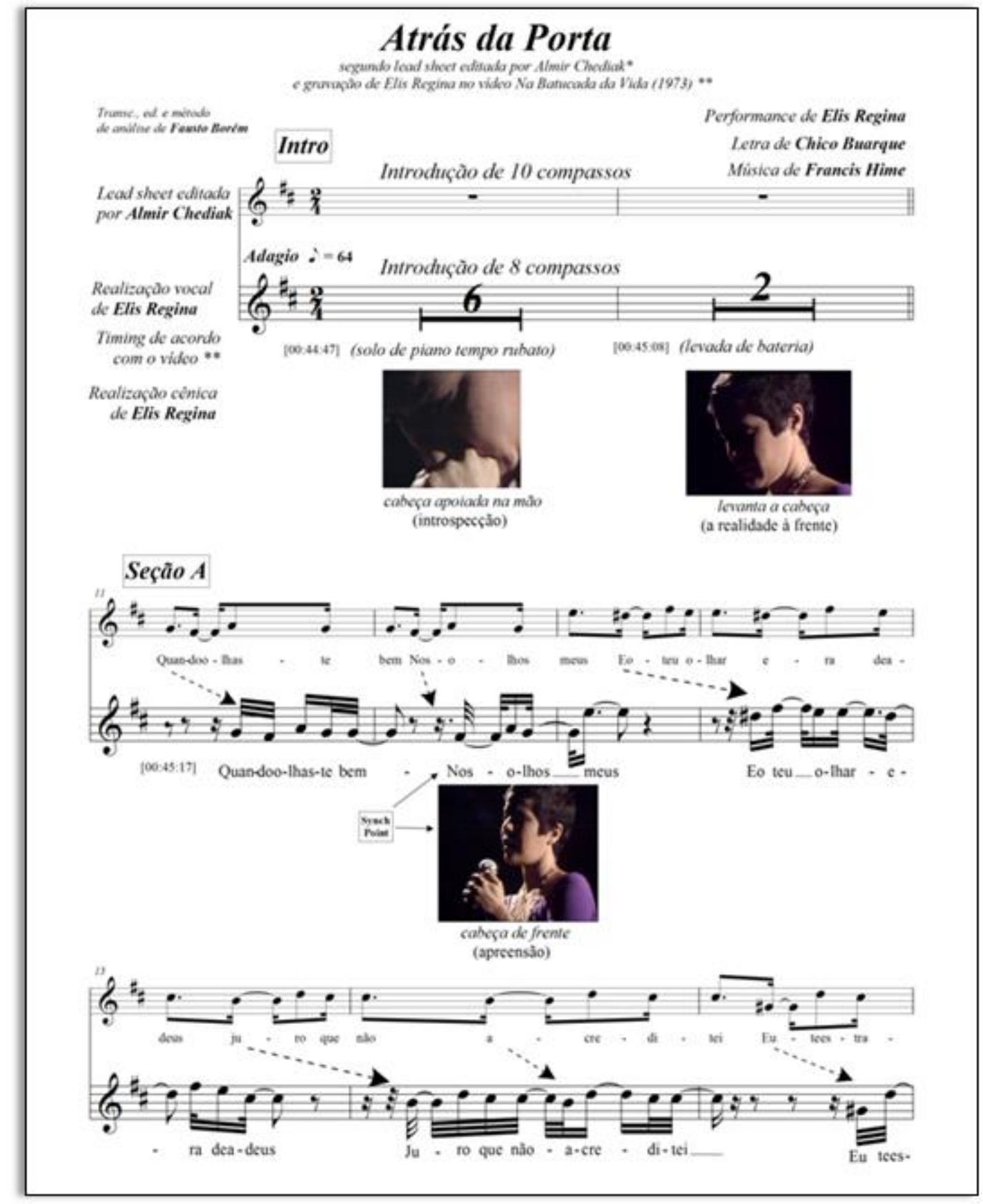


Figure 16 - Page from a complete EdiPA of "Atrás da porta" by Chico Buarque and Francis Hime, transcribed by Almir Chediak, performed by Elis Regina and filmed by Roberto de Oliveira (Regina, Buarque, Hime, Chediak and Oliveira, 2014), containing two realizations, photograms and analytical data information.

\section{4 - Final consideratons}

The lack of methodological tools for the analysis of music videos (Cook, 1998 p.v) motivated me to develop MaPA (Map of Audiovisual Performance) and EdiPA (Audiovisual Performance Edition), proposed and explained in this article. With them, I seek ways to facilitate the understanding of a variety of primary sources with great potential for representation and expression of the text-soundimage trinomial: video recordings of concerts, shows, operas, ballets, films, documentaries, interviews, reports, commercials and music videos. In these sources, outlining the relationships among facial expressions, major body gestures, props, scenery and lighting (which usually makes up the ambience of the musical realization) allow to understand stylistic aspects not only of performers but also composers, lyricists/poets/librettists (in the case of the sung music) and video directors. Both $M a P A$ and EdiPA, which can be treated as consecutive tools (one EdiPA is easily constructed from its respective MaPAs), are flexible to accommodate different analytical approaches and languages.

The content and construction process of a MaPA may be linked to the type of control exercised over the performance by the performer and/or by the photograph or film director. I note that most of recordings of shows and concerts, live or in studio, the quasi-spontaneous performance (as in most of the recordings of Elis Regina; see Figures 4, 5, 6, 7, 8 and 9 above) predominates. In this spontaneity type, one may observe, at the same time, great freedom in theatrical music realization, but also a careful planning and control of both sounds and choreography. In one end of the continuum containing the quasi-spontaneous performance, I situate the non-spontaneous performance (as exemplified in Caetano Veloso's video clip; see Figure 11), in which the images of the musical performance is under great control by the artists, but mainly by the video director, who acts as a co-composer of the interpretation. This kind of music video is commercially very effective and, therefore, pervades most of today's video clips. The recording of their images is posterior to the audio recording, which requires massive synchronization work of body movements (especially of the mouth) with what you hear on the playback. At the other extreme of the naturalness continuum of videos I situate the spontaneous performance (as exemplified in excerpts from Elis Regina's live recording, see Figure 10), which contents (or parts of it, as it is more common to happen) escapes the control of 
the musicians or the video director. Thus, not only unpredictable errors and improvisations are recorded, but also moments with deep and spontaneous emotions.

A MaPA can be built with a single frame (Figures 4, 5 and 6) to represent specific events and relationships at local levels of the music, such as details of facial expressions and Sync Points. MaPAs with a few photograms (Figures 7 and 8) allow the observation of events which relations occur at more general levels, such as indications of movements, articulations of Chunks and changes of Kinematics and Dynamics. As for MaPAs with more frames (Figures 9, 10 and 11), they usually can cover events and their relationships in more global levels, summarizing the whole of a video, such as large scale relations of the music form, with their atmosphere or mood changes and respective Activation Contours.

The construction scope of an EdiPA generally follow the same amplitude of the MaPAs they are based on. EdiPas can be as short as, for example, one frame or two paired with a short excerpt of a music score. This type can be useful to recover performance practices not available in text, but documented from oral tradtion by means of interviews (Figure $2 b$ ) and to indicate Sync Points among text, music and movements (Figure 15a, 15b and 15c). EdiPAs with various musical excerpts or longer musical excerpts let us compare Activation Contours, Kinematics and Dynamics of different Chunks. EdiPAs of complete songs (Figure 16) may be useful to readers interested in both understanding analysis and synthesize data of the compositional and interpretative processes, as well as instrumentalists, singers and conductors interested in performing music by means of corroborating, diversifying or opposing to stylistic traits of that performance. Finally, EdiPAs can be constructed by pairing music scores with images of their spectrograms taken from audio files (Figures 12 and 13), which can reveal accurately tempo, articulation, intensity, timbre and timing data of events.

\section{References}

\section{References of texts}

1. Albin, Ricardo Cravo. (2003). O Livro de ouro da MPB: a história de nossa música popular de sua origem até hoje. Preface by Martinho da Vila. Rio de Janeiro: Ediouro, 2003.

2. Auslander, Philip. (2005). Sound and vision: Record of the past or performance in the present? In: CHARM Symposium 1: Comparative perspectives in the study of recordings (Royal Holloway, University of London, 14 - 16 April, 2005); http://charm.cchcdn.net/redist/pdf/s1Auslander.pdf 
3. Birdwhistell, Ray L. (1952). Introduction to Kinesics: An Annotation System for Analysis of Body Motion and Gesture. Louisville: University of Louisville Press.

4. Birdwhistell, Ray L. (1970). Kinesics and Context: Essays on Body Motion Communication. Philadelphia: The University of Pennsylvania Press.

5. Borém, Fausto. (2006). “... Foda!”: a bossa das palavras, música e imagens de Caetano Veloso. ARJ-Arts Review Journal. n.3, n.2. Natal: ANPPOM/ABRACE/ANPAP.

6. (2014). Por uma análise da performance em vídeos de música, um "Mapa Visual de Performance" (MVP) e uma "Edição de Performance Audiovisual" (EPA). In: Anais do 1ํㅡㄹ Congresso da TeMA. Org. by Marcos da Silva Sampaio. Salvador: UFBA. p.100-108.

7. Borém, Fausto; Campos, João Paulo. (2016, in print). Técnicas estendidas do contrabaixo em arranjos crossover. Música Hodie. v.16, n.2. Goiânia: Universidade Federal de Goiás.

8. Borém, Fausto; Freire, Maurício. (2010). Cannon de Hermeto Pascoal: aspectos musicais e religiosos em uma obra-prima para flauta. Per Musi. n.22. Belo Horizonte: UFMG. p.63-79.

9. Borém, Fausto; Lopes, Leonardo; Lage, G. M. (2014). Nancy de Bertram Turetzky: Cinesiologia e Prática Deliberada da Técnica Estendida Arco + Pizz. no Contrabaixo. Revista Música Hodie. v.14, n.2, p.67-83. Goiânia: Universidade Federal de Goiás.

10. Borém, Fausto; Taglianetti, Ana Paula. (2016). Construção de uma performance cênica para as três modinhas imperiais de Lino José Nunes (17891847). Belo Horizonte: unpublished manuscript. 19p.

11. (2014a). A trajetória cênicomusical de Elis Regina. Per Musi. n.29. Belo Horizonte: UFMG. p.39-52.

12. (2014b). Texto-música-imagem de Elis Regina: uma análise de Ladeira da Preguiça, de Gilberto Gil e Atrás da porta, de Chico Buarque e Francis Hime. Per Musi.n.29, p.53-69. Belo Horizonte: UFMG. 
13. Burt, John W. (1994). Body, face and voice: nonverbal, expression of emotion in infancy. Philadelphia: Haheman University (Ph.D. Dissertation in Clinical Psychology and Creative Arts Therapy).

14. Cielo, Carla A. et al. (2011). Músculo tireoaritenoidiano e som basal: uma revisão de literatura. Revista Brasileira de Fonoaudiologia. v.16, n.3, p. 362-369.

15. Clayton, Martin. 2007. Analysing video recordings of musical performances. In: CHARM Symposium 4: Methods for analysing recordings. Eghan: Royal Holloway, University of London, April 12-14, 2007. In: http://www.charm.rhul.ac.uk/about/symposia/p7_10_1.html

16. Cook, Nicholas. (in print). "Song into video into film: 'Bohemian Rhapsody', 'Wayne's World' and beyond". In: The Cambridge Companion to Film Music, Ed. by Peter Franklin and Robynn Stolwell. Cambridge: Cambridge University Press, forthcoming.

17. (2013). Beyond the score: music as performance. Oxford: Oxford University Press.

18. (1998). Analyzing musical multimedia. Oxford: Oxford University Press.

19. Cook, Nicholas; Chan, Carol (Org.). (2007). Proceedings of CHARM RMA Annual Conference: Musicology and Recordings. Egham, Inglaterra: CHARM/Royal Holloway, University of London.

20. Dowling, W. Jay; Harwood, Dane L. (1986). Music cognition. Academic Press Series in Cognition and Perception. New York: Academic Press.

21. Du, Shichuan; Tao, Yong; Martinez, Aleix M. (2014). Compound facial expressions of emotion. Proceedings of the National Academy of Sciences of the United States of America. PNSA, March. In: www.pnas.org/content/111/15/E1454.

22. Du, Shichuan; Martinez, Aleix M. (2011). The Resolution of facial expressions of emotion. Journal of Vision v.11, n.13, p.1-13. In: http://www.journalofvision.org/content/11/13/24.

23. Ekman, Paul. (1972). Universals and cultural differences in facial expressions of emotion. In: Nebraska Symposium on Motivation. Ed. by J. K. Cole, v.19. Lincoln: University of Nebraska Press. 
24. Ekman, Paul. (1999). Facial expressions. In: Handbook of cognition and emotion. Org. by T. Dalgleish and M. Power. Chapter 16, p.301-320. New York: John Wiley \& Sons.

25. Ekman, Paul; Friesen, Wallace V. (1986). A New pan-cultural facial expression of emotion. Motivation and emotion. v.10, n.2. p.159-168. Plenum Publishing.

26. (2003) Unmasking the face: A guide to recognizing emotions from facial expressions. Los Altos, California: Malor Books.

27. Ekman, Paul; Keltner, Dacher. (1997). Universal facial expressions of emotion: an old controversy and new findings. Org. by Ullica Segerstrale and Peter Molnár. In: Nonverbal communication: where nature meets culture, p.27-46. Manwah, New Jersey: Lawrence Erlbaum Associates.

28. Feaster, Patrick. (2010). Édouard-Léon Scott de Martinville: An Annotated Discography ARSC Journal v.51, n.1, p.43-82. Association for Recorded Sound Collections.

29. Ferreira, Mauro. (2005). Elis Regina Carvalho Costa: DVD com especial da Globo exibido em 1980 flagra cantora em momento iluminado. In: Isto é: Gente. Revista online. Posted January 09, 2005.

http://www.terra.com.br/istoegente/333/diversao_arte/musica_elis_regina.htm

30. Foreman, Judy. (2003). A Conversation with Paul Ekman: The 43 Facial Muscles That Reveal Even the Most Fleeting Emotions. New York Times, August 5, 2003. http://www.nytimes.com/2003/08/05/health/conversation-with-paul-ekman-43facial-muscles-that-reveal-even-most-fleeting.html.

31. Gil, Gilberto. (2003). Gilberto: todas as letras. Org. Carlos Rennó. Texts by Arnaldo Antunes and José Miguel Wisnik. Special participation of Marcelo Fróes. Revised edition. São Paulo: Companhia das Letras.

32. Gomery, Douglas. (1985). The Coming of sound. In: Film sound, p.6-24. Org. by Elizabeth Weis and John Belton. New York: Columbia University Press.

33. Goodwin, Andrew. (1992) Dancing in the distraction factory: music television and popular culture. Minneapolis: University of Minnesota Press. 
34. Gurry, Néstor Ramón Cordero. (2014). A Voz de tenor: bases históricas da pedagogia vocal a partir do Bel Canto até os conceitos metodológicos da atualidade. Belo Horizonte: UFMG (Masters Thesis in Music).

35. Haga, Egil. (2008) Correspondences between music and body movement. Oslo: University of Oslo, Faculty of Humanities. (Doctorate Dissertation in Music).

36. Hall, Susan. (2005). Biomecânica básica. 4th ed. Rio de Janeiro: Guanabara Koogan.

37. Hamill, J.; Knutzen, K. M. (2008). Bases biomecânicas do movimento humano. São Paulo: Manole.

38. Izard, Caroll E. (1982). Measuring emotions in infants and children. New York: Cambridge University Press.

39. Izard, Caroll E.; Dougherty, L. M. (1980). A System for Identifying Affect Expressions by Holistic Judgments (AFFEX). Newark: Instructional Resources Center/University of Delaware.

40. Izard, Caroll E.; Dougherty, L. M. (1982). Two complementary systems for measuring facial expressions in infants and children. In: Measuring emotions in infants and children. Org. by C. E. Izard. New York: Cambridge University Press.

41. Juslin, Patrik N. (2001). Communicating emotion in music performance: a review and theoretical framework. In: Music and emotion: theory and research, p.309-337. Org. by P. Juslin and J. A. Sloboda. New York: Oxford University Press.

42. Juslin, Patrik N.; Laukka, Petri. (2003). Communication of Emotions in Vocal Expression and Music Performance: Different Channels, Same Code? Psychological Bulletin v.129, n.5, p.770-814. American Psychological Association.

43. Dahl, Sofia. (2006). Production and perception of gestures in music performance. In: Annals of International Conference on Music and Gesture, p.1-6. Manchester, UK.

44. Torres-Eliard, Kim; Labbé, Carolina; Grandjean, Didier. (2012). Towards a Dynamic Approach to the Study of Emotions Expressed by Music. In: Annals of INTETAIN 2011 (Conference on Intelligent Technologies for Interactive Entertainment), LNICST 78 (Lecture Notes of the Institute for Computer Sciences, 
Social-Informatics and Telecommunications Engineering), p. 252-259. Org. by A. Camurri, C. Costa and G. Volpe. Swiss Center for Affective Sciences, Neuroscience of Emotion and Affective Dynamics Laboratory. Geneva, Switzerland.

45. Kawase, Satoshi. (2014). Importance of Communication Cues in Music Performance according to Performers and Audience. International Journal of Psychological Studies. v.6, n.2, p.49-64. Canadian Center of Science and Education.

46. Keltner, Dacher; Ekman, Paul. (2008). Facial expression of emotion. In: Handbook of emotions. $2^{\mathrm{a}}$ ed. Cap.15. Org. by Michael Lewis and Jeannette M. Haviland-Jones. New York: Guildford Publications.

47. Kob, Malte; Heinrich, Nathalie; Herzel, Hanspeter; Howard, David; Tokuda, Isao; Wolfe, Joe. (2011). Analysing and understanding the singing voice: recent progress and open questions. Current Bioinformatics. v.6, n.3, p.362-374.

48. Laban, Rudolf. (1978). Domínio do movimento. Org. and ed. by Lisa Ullmann. Translated by Anna Maria Barros de Vecchi and Maria Silvia Mourão Netto. Preface Maria Duschenes. São Paulo: Summus Editorial.

49. Lage, Guilherme M.; Borém, Fausto; Benda, Rodolfo N.; Moraes, Luiz Carlos. (2002). Aprendizagem motora na performance musical: reflexões sobre conceitos e aplicabilidade. Per Musi, p.14-37. Belo Horizonte: UFMG.

50. Levenson, Robert W. (2014). The Autonomic Nervous System and Emotion. Emotion Review, v.6, n.2 (April), p.100-112. International Society for Research on Emotion/Sage.

51. Lopes, Leonardo. (2015). Movimentos básicos na performance do contrabaixo: descrição e análise cinesiológica. Belo Horizonte: UFMG. (Thesis of Masters in Music Performance).

52. Magill R. A. (2000). Aprendizagem motora: conceitos e aplicações. 5.ed. São Paulo: Edgard Blucher.

53. Merrell, Floyd. (2001). Charles Sanders Peirces's concept of the sign. In: The Routledge Companion to semiotics and linguistics, p.28-39. Org. by Paul Cobley. Londres: Routledge. 
54. Parr, Alil. (2016). Improve Your Vocabulary With the "Wheel of Feelings". Mental floss. In: http://mentalfloss.com/article/64182/improve-your-vocabularywheel-feelings.

55. Perotti, Deniele; Borém, Fausto. (2016). Relações texto-música-imagem de Elis Regina em Me deixas louca. Série Diálogos Musicais da Pós: Práticas de Performance, p.20-32. Belo Horizonte: Minas da Música.

56. Piedade, Acácio Tadeu de Camargo. (2003). Brazilian Jazz and Friction of Musicalities. In: Planet Jazz: Transnational Studies of the "Sound of Surprise", p.4158. Ed. by E. Taylor Atkins. University Press of Mississippi.

57. Pinheiro, Marcelo. (2015). Elis Regina, segundo Cesar Camargo Mariano: nos 70 anos da cantora, o compositor, arranjador e produtor radicado nos EUA fala sobre a intimidade artística entre ele e a saudosa Pimentinha. In: http://brasileiros.com.br/2015/03/elis-regina-segundo-cesar-camargo-mariano.

Terra, Seção Brasileiros. Posted: March 17, 2015; updated: May 2, 2015; accessed: February 20, 2016.

58. Plutchik, Robert. (2001). The Nature of Emotions. American Scientist, n.89, p.344-350. Sigma Xi, The Scientific Research Society. In: http://www.americanscientist.org/my_amsci/restricted.aspx?act=pdf\&id=276215 0868143.

59. Ribeiro, Alfredo; Borém, Fausto; Rocha, Edite. (2015). Variações de timing e escolhas estéticas na gravação histórica do Andante do Concerto Op.3 de Serge Koussevitzky. In: Anais do 25ํㅡ Congresso da ANNPOM. Vitória: ANPPOM.

60. Ribeiro, Alfredo; Borém, Fausto. (2015). Concerto Op.3 de Serge Koussevitzky: rubati, vibrati e portamenti em uma gravação histórica de 1929. Série Viva Música. Belo Horizonte: UFMG (Power Point Presentation).

61. (2012). Portamento e vibrato no Andante do Concerto Op.3: práticas de performance do contrabaixista-compositor Serge Koussevitzky. In: Anais do 22º Congresso da ANPPOM, p.1832-1840. João Pessoa.

62. Rottenberg, Jonathan; Gross, James J.; Wilhelm, Frank H.; Najmi, Sadia; Gotlib, Ian H. (2002) Crying Threshold and Intensity in Major Depressive Disorder. Journal of Abnormal Psychology, v.111, n.2, p.302-312.Washington, DC: American Psychological Association. 
63. Russell, James A. (1980) A circumplex model of affect. Journal of Personality and Social Psychology, v.39, n.6, p.1161-1178.

64. Rengel, Lenira Peral. (2001). Dicionário Laban. Campinas: Unicamp. (Thesis of Masters in Arts).

65. Sauter, Disa. (2006). An investigation into vocal expressions of emotions: the roles of valence, culture, and acoustic factors. Londres: University College London (Ph.D Dissertation).

66. Schmidt, R. A.; Wrisberg, C. A. (2001). Aprendizagem e performance motora: uma abordagem da aprendizagem baseada no problema. Trad. By Ricardo Petersen. 2.ed. São Paulo: Artmed.

67. Shere, Jeremy. (2013). What causes a lump in your throat? In: Moment of Science. Posted March 19, 2013; accessed February 15, 2015.

http://indianapublicmedia.org/amomentofscience/a-lump-in-your-throat.

68. Stern, Daniel. (2000). The Interpersonal World of the Infant. New York: Basic Books.

69. (2004) The Present Moment. In Psychotherapy and Everyday Life. New York: W. W. Norton \& Company, Inc.

70. Tagg, Philip. (2011). Análise musical para "não-musos": a percepção popular como base para a compreensão de estruturas e significados musicais. Trad. de Fausto Borém. Per Musi, n.23, p.7-18.. Belo Horizonte, UFMG.

71. Ulhôa, Martha T. (1999). Métrica derramada: prosódia na canção brasileira popular. Brasiliana. n.2, (Jan.), p.48-56.. Rio de Janeiro: Academia Brasileira de Música.

72. Wise, Thimothy. (2007). Yodel species: a typology of falsetto effects in popular music vocal styles. Radical Musicology. v.2. Ed. by Richard Middleton and Ian Biddle. Newcastle: Newcastle University (Centre for Music Studies). 


\section{References of music scores}

73. Gil, Gilberto. (1992). Ladeira da Preguiça. In: Songbook: Gilberto Gil. Edition and production by Almir Chediak, v.2, 3⿳⺈ ed, p.96-97. Rio de Janeiro: Lumiar.

74. Koussevitzky, Serge. (1985). Concerto Op.3, N.1-3, for string bass and piano. Série Kalmus Classic Edition (Score K-04459). New York: Kalmus.

75. Pascoal, Hermeto. (2010). Partitura de Cannon (dedicada a Cannonball Aderley), para flauta, humming na flauta e sons pré-gravados. Per Musi, n.22, p.80-82. Belo Horizonte: UFMG.

76. Regina, Buarque, Hime, Chediak and Oliveira. (2014). Atrás da porta. Lead sheet edited by Almir Chediak e recorded by Elis Regina in "Batucada da Vida" (video). Per Musi, n.29, p.70-74. Ed. by Fausto Borém. Belo Horizonte: UFMG.

\section{References of videos}

77. Dickson, William. (2013). The First American Movies (1891- 1895) - Thomas Edison - W. Dickson - Kinetoscope, Kinetophone. In: www.youtube.com/watch?v=vfqUjBDIkT8 (video of 1 minute and 1 second from 1894-1895, published on Youtube by Cinema History on January 7, 2013, accessed on January 20, 2016).

78. Miéle, Luis Carlos. (2009). Lennie Dale - Trecho do documentário Dzi Croquettes 2010.mpg. In: www.youtube.com/watch?v=kbOWiPeLAvw (Vídeo of 12 minutes and 9 seconds, from the documentary by Tria Produções and Canal Brasil, directed by Tatiana Issa and Raphael Álvarez, published on Youtube on December,3, 2010 by eduardolott1; accessed on February 2, 2016).

79. Regina, Elis; Gil, Gilberto; Faro, Fernando. (1973). Elis Regina - "Ladeira da Preguiça" - Ensaio - MPB Especial. In: www.youtube.com/watch?v=gNXz5flgWhQ (video of 2 minutes and 52 seconds, from the DVD Elis Regina: MPB Especial, 1973 and DVD Trama AA 100000, published on Youtube by "Trama TV" on October 15, 2007; accessed on Februar, 2, 2016). Directed by Fernando Faro. With: Elis Regina (voice, interviews); César Camargo Mariano (piano); Hélio Delmiro (guitar); Luizão Maia (bass); Paulinho Braga (drums), among others.

80. Regina, Elis; Buarque, Chico; Hime, Francis; Oliveira, Roberto de. (1973). Elis Regina: Atrás da porta, 1973. In: www.youtube.com/watch?v=SJ2JatcXQx0 (video of 3 minutes and 49 seconds, from the DVD Na batucada da vida de 2006, published 
on Youtube by Jordão Qualquer on September 27, 2008; accessed on February 7, 2016). Directed by Roberto de Oliveira. With: Elis Regina (voice); César Camargo Mariano (piano); Hélio Delmiro (guitar); Luizão Maia (bass); Paulinho Braga (drums).

81. Regina, Elis; Buarque, Chico; Hime, Francis; Filho, Daniel. (1980). Elis Regina: Atrás da porta ao vivo. In: www.youtube.com/watch?v=35FPZR24djg (video of minutes and 38 seconds, from the series Grandes Nomes TV Globo; published on Youtube by "ninne" on April 18, 2006; accessed on February 7, 2016). With: Elis Regina (voice); César Camargo Mariano (keyboards, arrangements and conducting), Daniel Filho (Video direction, assisted by Maurício Nunes and João Paulo Carvalho).

82. Regina, Elis; Manzanero, Armando; Coelho, Paulo; Oliveira, Roberto de. (2006). Elis Regina: Me deixas louca.

In: https://www.youtube.com/watch? $\mathrm{v}=\mathrm{t} 08$ AusBApQA (video of 3 minutes and 5 seconds, from the DVD Falso Brilhante da Universal Music; published on Youtube by "Maria Elisa Horn Iwaya" on June 18, 2006, accessed on February 7, 2016). Directed by Roberto de Oliveira. With: Elis Regina (voice); special participation of César Camargo Mariano (keyboards and arrangements).

83. Veloso, Caetano. (2012). Caetano diz que 'bossa nova é mais foda que o tropicalismo'. In: TV Folha. Video of 3 minutes and 43 seconds, published on Dec 2, 2012 by TV Folha. In: https://www.youtube.com/watch?v=P8J4y5AZhMA.

84. Veloso, Caetano; Young, Fernando; Quinta-feira, Tonho. (2013). A Bossa nova é Foda. With: Caetano Veloso (compositions, voice, acting), Pedro Sá (guitar, voice, acting), Ricardo Dias Gomes (bass, electric pianos, voice, acting), Marcelo Callado (drums, voice, acting), Fernando Young and Tonho Quinta-Feira (video direction). Video with 4 minutes and 16 seconds, published on Youtube by Universal Music Brasil on April 15, 2013.

https://www.youtube.com/watch?v=orPhkLpX3ps.

\section{References of audios}

85. Koussevitzky, Serge; Luboshutz, Pierre. (1929). Koussevitzky Plays Koussevitzky (Concerto Op. 3, II. Andante). In: www.youtube.com/watch?v=1fTexStjP_A. Audio of 6 minutes and 33 seconds, published on Youtube by baroquecello on January 20, 2001. (Acessed on January 12, 2016). With Serge Koussevitzky (double bass) and Pierre Luboshutz (piano). Recorded on September 25, 1929; first released by RCA Victor 99-2000. 
86. Lee, Rita; Baptista, Arnaldo; Dias, Sérgio; Liminha. (1972). Tiroleite. In: Hoje é primeiro dia do resto de sua vida. With Rita Lee and Mutantes. Polydor, track 2 of side B (LP 2451.017).

87. Martinville, Édouard-Léon Scott de. (2008). Worlds First Audio Recording, 1860 - www.pastfinder.de. In: https://www.youtube.com/watch?v=s0fhEpxrFvo. Audio of 15 seconds from 1860 published on Youtube by Pastfinder on March 29, 2008.

88. Pascoal, Hermeto. (1977). Cannon. Audio of 5 minutes and 24 seconds, published on Youtube by jeromeknvb on October 4, 2010. In: www.youtube.com/watch?v=7wkCNhTC-0USlaves Mass. With: Hermeto Pascoal (flute and voice) with vocal participations of Flora Purim, Airto Moreira, Hugo Fattoruso, Raul de Souza and Laudir de Oliveira. Released by WEA/Warner (LP BS2980). 